\title{
Reproductive biology, embryonic development and matrotrophy in the phylactolaemate bryozoan Plumatella casmiana
}

\author{
Julian Bibermair ${ }^{1} \cdot$ Andrew N. Ostrovsky ${ }^{2,3}$ (D) $\cdot$ Andreas Wanninger ${ }^{1}$ (D) $\cdot$ Thomas Schwaha $^{1}$ (D)
}

Received: 15 January 2021 / Accepted: 18 May 2021 / Published online: 17 June 2021

(C) The Author(s) 2021

\begin{abstract}
Bryozoa is a phylum of aquatic, colonial suspension-feeders within the Lophotrochozoa. In the Phylactolaemata embryonic development occurs in an internal brood sac on the body wall accompanied by extraembryonic nutrition. Owing to previous contradictive descriptions, many aspects of their sexual reproduction require restudy. Consequently, this study analyses embryogenesis of the freshwater bryozoan Plumatella casmiana by serial sections, 3D reconstruction and transmission electron microscopy. Early embryos cleave and soon develop into blastulae with a small central cavity. The mesoderm forms by delamination starting from the distal side towards the proximal end. In later embryos two polypides form on the posterior side that ultimately will be covered by a ciliated mantle in the larva. Embryos increase in size during development and form temporary cell contacts to the embryo sac. Mesodermal cells of the embryo sac show signs of transcellular transport indicating that embryos are nourished by transferring nutrients from the maternal coelom towards the brood cavity. This study clarifies several details such as mesoderm formation and the onset of bud development. Embryos are connected to their respective embryo sacs by a variety of temporary cytoplasmic processes formed by both tissues during embryogenesis, including a 'placental' ring zone. Although ultrastructural data of these cell contacts are not entirely conclusive about their function, we suggest that embryos absorb nutrients via the entire surface. The close opposition of embryos to the embryo sac implies placentation as matrotrophic mode in phylactolaemate bryozoans, with embryo sacs acting as placental analogues.
\end{abstract}

Keywords Embryogenesis $\cdot$ Brooding $\cdot$ Matrotrophy $\cdot$ Placentation $\cdot$ Freshwater bryozoans $\cdot$ Plumatellidae

\section{Introduction}

Bryozoans are a group of mostly colonial, suspension-feeding lophotrochozoans occurring in both marine and freshwater habitats (Ryland 1970, 2005; McKinney and Jackson 1989). Individual animals of a colony are termed zooids and are traditionally, but artificially, divided into a polypide and a cystid (Ryland 2005; Schwaha 2020a). The former comprises a ciliated tentacle crown (lophophore), the digestive tract, and associated neural and muscular tissue. The cystid is the body

Thomas Schwaha

thomas.schwaha@univie.ac.at

1 Department of Evolutionary Biology, Unit for Integrative Zoology, University of Vienna, Althanstraße 14, 1090 Vienna, Austria

2 Department of Invertebrate Zoology, Universitetskaja nab. 7/9, Saint Petersburg State University, Saint Petersburg 199034, Russia

3 Department of Palaeontology, University of Vienna, Althanstraße 14, 1090 Vienna, Austria wall with the epidermis and a peritoneal layer termed endocyst and its cuticle, the ectocyst. Besides coloniality, the retraction process of the polypide into the cystid is one of the major characteristics of bryozoans (Mukai et al. 1997; Schwaha et al. 2020). There are two major clades of bryozoans, the Phylactolaemata, a group of sole freshwater bryozoans, and the Myolaemata (Schwaha et al. 2020). The latter comprises the exclusively marine Stenolaemata, with the Cyclostomata as the only extant clade, and the predominantly marine Gymnolaemata, which includes the most speciose and marine group of Cheilostomata that evolved from ctenostome-like ancestors (Waeschenbach et al. 2012; Taylor and Waeschenbach 2015). In contrast to cheilostome and cyclostome bryozoans, phylactolaemates and ctenostomes create a non-calcified ectocyst consisting of gelatinous or chitinous (sometimes sand-encrusted) material. Phylactolaemates, in general, make larger zooids and have a horseshoe-shaped lophophore, an epistome and a regular grid of body wall musculature (Wood 2014; Schwaha 2020b; Schwaha et al. 2020). Six or seven family-level clades belong to Phylactolaemata 
(Schwaha 2020b). Plumatellidae is the most speciose taxon with a branching colony morphology. Ectocysts of its members are gelatinous, particle-encrusted or chitinous. Colonies of most species are repent, but some are erect and branching (Wood 2014). Plumatellids are the most studied family and most investigations focus on Plumatella repens and $P$. fungosa.

Starting from pioneering research on phylactolaemate bryozoans of van Beneden (1839), Dumortier and van Beneden (1850) and Allman (1856), various aspects of their sexual reproduction and embryonic development were studied in the past (summarized in Table 1; reviewed in Mukai 1982; Reed 1991; D'Hondt 2005, Ostrovsky 2020), but data on the development from the zygote to the larva date back to the late nineteenth and early twentieth century and many aspects of phylactolaemate sexual reproduction, including fertilization, oviposition and embryonic development including mesoderm formation, remain unknown or require reinvestigation (see Hyman 1959; Mukai 1982).

Similar to many gymnolaemates (Ostrovsky 2013a, b, Ostrovsky et al. 2006, 2007, 2009a, b), phylactolaemates incubate their embryos in brood sacs. The embryonic development is accompanied by a temporary placenta-like structure that was previously considered as putative site of extraembryonic nutrition (Davenport 1891; Mukai 1982; Reed 1991; Hyman 1959; Ostrovsky 2013a, b; Ostrovsky et al. 2016). The contact cell zone referred to as 'placenta' forms a ring around the embryo in the genera Plumatella (Korotneff 1890, Kraepelin 1892, Braem 1897) and Hyalinella (Mukai 1982), a terminal 'placentulum'/'placenta-like neck' in Cristatella mucedo (Jullien 1890; Davenport 1891) or 'placental disc' in Fredericella sultana (Braem 1908b); its origin remains unclear, however. Also, while the term 'placenta' implies a nutritive function, these structures might simply anchor embryos inside the brood sac (Davenport 1891). One way to demonstrate that energy is being provided to the developing embryo from these tissues is through TEM showing exocytosis and endocytosis.

The present study analyses embryogenesis in the phylactolaemate bryozoan Plumatella casmiana by histological sectioning, 3D reconstruction and TEM. The main aims are to address open questions on the development of phylactolaemate bryozoans such as mesoderm formation or cell contacts during embryogenesis and its relevance for matrotrophy and extraembryonic nutrition.

\section{Material and methods}

Colonies of Plumatella casmiana (Fig. 1) were collected from the pond of the Faculty of Fisheries at the Kasetsart University, Bangkok, Thailand. Colony pieces were fixed in $2 \%$ glutaraldehyde (GA) in $0.01 \mathrm{M}$ phosphate buffer (PB), $\mathrm{pH}$
7.2, for $1 \mathrm{~h}$ and rinsed several times in PB. Samples were postfixed in $1 \%$ aqueous osmium tetroxide $\left(\mathrm{OsO}_{4}\right)$ for $1 \mathrm{~h}$ and rinsed in double-distilled water. Samples were afterwards dehydrated with acidified 2-2-dimethoxypropane (DMP) prior to embedding in Agar Low Viscosity resin (Agar Scientific Ltd, Essex, UK) using acetone as intermediate. Additional mounted zooids of sexually active Plumatella sp. from the teaching material of the University of Vienna was examined for overview images.

\section{Sectioning and 3D reconstruction}

Ribbons of serial semithin sections of $1.5-\mu \mathrm{m}$ thickness were produced using a Histo-Jumbo diamond knife (Diatome, Biel, Switzerland) on a Leica UC6 ultramicrotome (Leica Microsystems, Wetzlar, Germany) (for details see Ruthensteiner 2008). Sections were stained with toluidine blue for $10-15 \mathrm{~s}$ at $60^{\circ} \mathrm{C}$. Before sealing slides with a cover slip, single sections were chosen for resectioning to allow for TEM analysis. For this, excessive adhesion of sections was reduced by keeping slides on the heat plate for just a short duration until the water had evaporated.

Embryos of different developmental stages were photographed with a Nikon NiU compound microscope with a Nikon Ds-Ri2 camera (Nikon, Tokyo, Japan). Image stacks were then converted to grayscale with Photoshop CS6 (Adobe, San Jose, CA) and imported into the reconstruction software Amira 6.3 (Mercury Computer Systems, Chelmsford, USA). Images were automatically aligned using the alignment tool of Amira with some manual corrections. Structures were segmented manually with interpolation between sections. Surfaces were created with the SurfaceGen module of Amira. Optimisation of surfaces was conducted by iterative triangle reduction and smoothing steps. Snapshots of reconstructed embryos were taken with the Amira software.

\section{Transmission electron microscopy}

Utrathin sections of $60 \mathrm{~nm}$ were prepared by resectioning semithin sections (for details see Handschuh et al. 2013). Unsealed sections were first screened for embryos, which were afterwards isolated by cutting the borders of the section with a razor blade. Afterwards a drop of Milli-Q water or double-distilled water was placed next to the section. Sections were lifted to allow for waterflow underneath the section on one side first, followed by full detachment by subsequent mechanical lifting. The detached section was mounted on a trimmed resin block slightly larger than the section of interest. Prior to mounting of the section, a droplet of double-distilled water was placed on the block surface. Then, the detached section was transferred to the block surface with a needle. Adherence of the sections was achieved by 
Table 1 Summary of most important studies focusing on phylactolaemate sexual reproduction and development

\begin{tabular}{|c|c|c|c|}
\hline Family & Species & Focus & Reference \\
\hline \multirow[t]{6}{*}{ Cristatellidae } & \multirow[t]{6}{*}{ Cristatella mисеdo } & Gametogenesis & Braem 1908a \\
\hline & & Oogenesis, embryology & Korotneff 1890 \\
\hline & & Oogenesis, embryology & Jullien 1890 \\
\hline & & Embryology & Davenport 1891 \\
\hline & & Larval structure & Schölzel 1951 \\
\hline & & Spermiogenesis, sperm ultrastructure & Lützen et al. 2009 \\
\hline \multirow[t]{4}{*}{ Fredericellidae } & \multirow[t]{4}{*}{ Fredericella sultana } & Oogenesis, embryology & Braem 1908b \\
\hline & & Sperm structure & Braem 1908a, b \\
\hline & & Larvae & Brien 1953 \\
\hline & & Larval structure & Gruhl 2010 \\
\hline \multirow[t]{6}{*}{ Lophopodidae } & \multirow[t]{4}{*}{ Asajirella gelatinosa } & Ovary structure & Oka 1891 \\
\hline & & Sperm, larval structure & Oda and Nakamura 1980 \\
\hline & & Oogenesis & Tazima et al. 1984 \\
\hline & & Spermiogenesis & Tazima et al. 1993 \\
\hline & Lophopus crystallinus & Gametogenesis, embryology & Marcus 1934 \\
\hline & Lophopodella carteri & Embryology & Oka and Oda 1948 \\
\hline Pectinatellidae & Pectinatella magnifica & Larval structure & Oda 1974 \\
\hline \multirow[t]{21}{*}{ Plumatellidae } & Plumatella casmiana & embryology & Mukai 1982 \\
\hline & P. evelinae & Gametogenesis & Marcus 1941 \\
\hline & P. fruticosa & Larval structure & Allman 1856 \\
\hline & \multirow[t]{15}{*}{ P. fungosa } & Embryology, larval structure & Allman 1856 \\
\hline & & Embryology & Metschnikoff 1871 \\
\hline & & Embryology & Nitsche 1872 \\
\hline & & Embryology & Reinhard 1881 \\
\hline & & Spermiogenesis & Korotneff $1887 \mathrm{a}$ \\
\hline & & Embryology & Korotneff $1887 \mathrm{~b}$ \\
\hline & & Embryology & Korotneff 1890 \\
\hline & & Gametogenesis, embryology & Braem 1890, 1897 \\
\hline & & Gametogenesis, embryology & Kraepelin 1892 \\
\hline & & Spermiogenesis & Retzius 1909 \\
\hline & & Spermiogenesis & Braem 1908a \\
\hline & & Embryology & Brien 1953 \\
\hline & & Sperm structure & Franzén 1981, Franzen 1982 \\
\hline & & Larval morphology & Franzén and Sensenbaugh 1983 \\
\hline & & Larval morphology and metamorphosis & Sensenbaugh and Franzén 1998 \\
\hline & Plumatella mukaii & Embryology & Mukai 1982 \\
\hline & \multirow[t]{2}{*}{ Hyalinella punctata } & Larvae & Rogick 1939 \\
\hline & & Embryology & Mukai 1982 \\
\hline
\end{tabular}

placing the block in the oven for at least $30 \mathrm{~min}$ (and up to several hours) at $60^{\circ} \mathrm{C}$. Afterwards, it was trimmed to a small area of interest. Subsequent ultrathin sections were placed on copper grids, contrasted with $1 \%$ uranyl-III-acetate (UA) for 8 minutes, followed by $8 \mathrm{~min}$ in $2.5 \%$ lead citrate (Laurylab, Brindas, France) with at least three rinses in double-distilled water after each medium. Transmission electron microscopy was performed on a Zeiss Libra 120 (Zeiss, Oberkochen, Germany). Images were taken with a post-column CCD camera (Sharp:eye TRS $(2 \times 2 \mathrm{k})$; Tröndle, Moorenwies, Germany) and the image SP software (Sysprogs OÜ, Kaiserslautern, Germany). 
Fig. 1 Plumatella casmiana. a and b Overview of colonies showing the branching growth pattern. $\mathbf{c}$ Detail of a piece of a colony showing extended lophophores
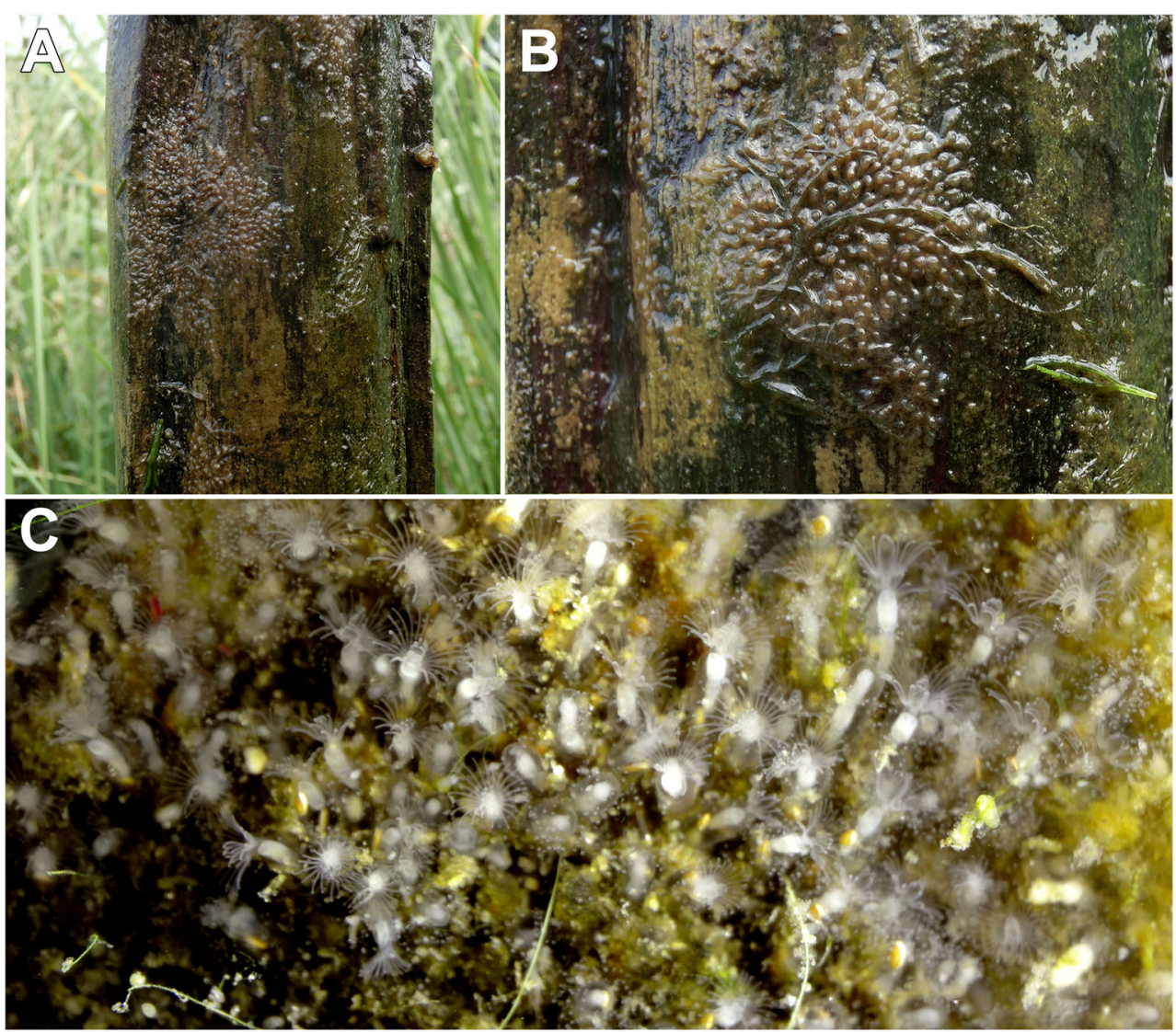

\section{Results}

\section{Position and formation of reproductive organs}

Fertile zooids show a regular arrangement of polypide buds on the oral side of the cystid, followed by an ovary and the embryo sac towards the distal side (Fig. 2b). The ovary lies proximal of the embryo sac, which is closest to the orifice (Figs. 2, 3). The first developing female germ cells are detectable in the peritoneal layer of the endocyst. They gradually enlarge and differentiate into oocytes with a thin layer of peritoneal cells (Figs. 2c, 3). Fully formed ovaries are grape-shaped, contain 8-12 mature oocytes and protrude into the coelomic cavity with the oldest (i.e. largest) oocytes situated in its proximal part (Figs. 3c, 4a).

The embryo sac forms slightly later than the ovary and is always closest to the orifice (Fig. 2b). The epidermal and the peritoneal layers of the endocyst are both involved in its formation (Fig. 3). Based on previous studies and for better comparability, these two maternal layers are herein designated as ectodermal layer and mesodermal layer of the embryo sac, corresponding to the epidermis and peritoneum, respectively. At the beginning of the formation of the embryo sac, the epidermal cells become highly prismatic and protrude towards the coelomic cavity to form a small internal bulge. Internally, the sac is lined by a thin peritoneum (Fig. 3). Similar to the polypide buds, the regular body wall musculature vanishes at the site of the proliferating embryo sac (Fig. 5a-d). Cell proliferation leads to an elongated embryo sac suspended in the coelomic cavity. The outer surface remains as a thin mesodermal layer of the embryo sac, the ectodermal, and internal layer remains as a thin layer in the proximal, suspended part of the sac, whereas it forms a dense plug of maternal ectodermal cells in the distal attachment area (Fig. 3d). These ectodermal cells stain less intense on the sections than surrounding cells (Fig. 4c).

\section{Gonads}

In young and more advanced ovaries, the younger/smaller oocytes are located closer to the body wall, whereas the older/larger ones are situated on the side protruding into the body cavity (Fig. 3c) each being surrounded by flattened follicle cells (Fig. 4a). Mature oocytes (see Table 2 for size) are oligolecithal with few yolk granules of various shape and size in the cytoplasm and contain a large nucleus usually with two nucleoli (Figs. 4a, d, 6a, 7d). Fully developed ovaries persist during embryonic development and can reach sizes similar to embryo sacs with advanced larvae. Although the ovary is often situated close to the embryo sac (Figs. 3, 4D), a direct contact was not found. Neither fertilisation nor oocyte transfer were observed in this study. Occasionally, however, single 

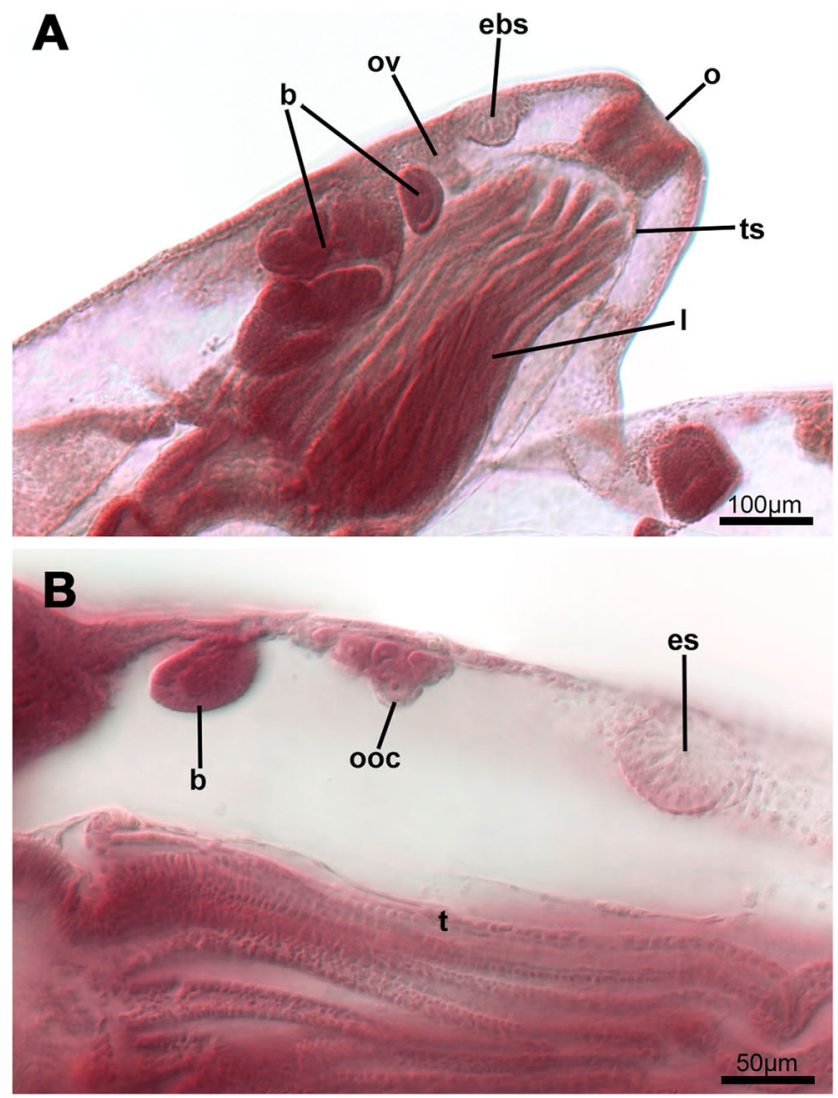

Fig. 2 a, b Whole mounts of autozooids of Plumatella sp. a General view of a zooid with retracted polypide. b Close-up of the cystid wall showing a young polypide bud, an ovary with few oocytes and a developing embryo sac. Abbreviations: $b$ bud, ebs embryo sac, $l$ lophophore, $o$ orifice, $o o c$ oocytes, $o v$ ovary, $t$ tentacles, $t s$ tentacle sheath oocytes are situated in the coelomic cavity of the maternal zooids.

Spermatogenic tissue is usually formed simultaneously with female germ cells. It is differentiated as grape-like clusters along the funiculus (Fig. 4b). Individual sperm cells were sporadically found in the coelom.

\section{Development of the embryo and embryo sac}

\section{Early stages}

The earliest encountered stage was an embryo that consists of several blastomeres but lacks a blastocoel, i.e., a pre-blastula/ morula stage (Fig. 4c). The next stage was a blastula of approximately 20 cells with a small central blastocoel (Figs. $4 \mathrm{~d}$, 5c, d, 8a, 9b). The embryonic cells show large nuclei with intensely stained nucleoli. In these early embryos, a thin unicellular ectodermal lining of the embryo sac still entirely surrounds the embryos in the proximal, suspended part of the sac (Fig. 4c). Starting from early blastula stages, the ectodermal cells vanish in this area (Fig. 5c, d). Consequently, the maternal ectodermal cells remain only in the upper/distal part of the brood sac, above the upper/posterior pole of the embryo as a dense cluster of large, often elongated, cells (Figs. 8, 9, 10, 11, 12). A central lumen is sometimes present in this cell mass (Fig. 10c).

The peritoneal cells that internally line the ectoderm cells of the embryo sac are cubic in shape in early stages. Nuclei of these cells slightly vary in size and amount of nucleoli.
Fig. 3 Ovary and embryo sac formation in Plumatella sp. a Early ovary in the body wall. Embryo sac formation occurs next to the ovary with its initial stage detectable by proliferation of the epidermal layer. $\mathbf{b}$ More progressed stage than in ' $a$ ' with the ovary and embryo sac protruding more into the body cavity of the zooid. $\mathbf{c}$ The oocyte number increases, and the largest and most mature oocytes are situated at the free end of the ovary towards the coelomic cavity. d Embryo sac with enclosed early embryo in the proximal part. The distal part towards the body wall is plugged by maternal cells from the epidermis. Abbreviations: $b$ bud, $e$ embryo, ebs embryo sac, ese embryo sac ectoderm, esm embryo sac mesoderm, mec maternal ectodermal cells, ooc oocyte, $o v$ ovary
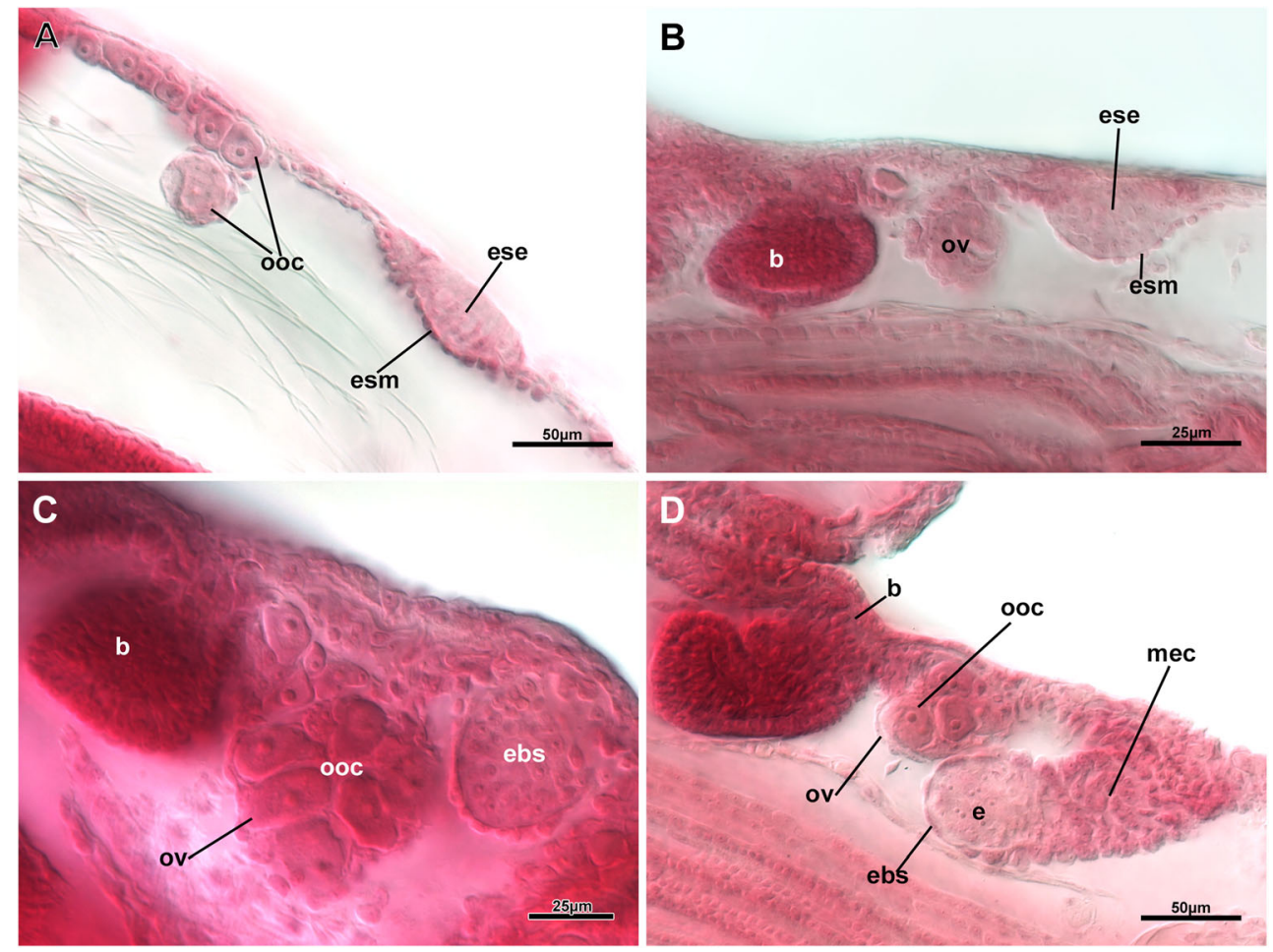
Fig. 4 Gonads and early embyo sac of Plumatella casmiana (semithin sections a, c, d), and whole-mount of Plumatella sp. (b). a Ovary with several oocytes. b Testes at the funiculus. Spermatids contain mostly the nucleus (insert). c Early cleavage stage with an embryo consisting of several blastomeres located at the free end of the embryo sac. The maternal ectodermal lining of the embryo covers the entire embryo (dashed line). $\mathbf{d}$ Oblique section of a blastula stage with commencing mesoderm formation (arrowheads indicate first mesodermal cells delaminating from the ectoderm). The maternal ectodermal lining persists (dashed line).

Abbreviations: bwm body wall musculature, $e$ embryo, $e b s$ embryo sac, $e d$ epidermis (ectodermal origin), ese embryo sac ectoderm, esm embryo sac mesoderm, $f u$ funiculus; mec maternal ectoderm cells, $n u$ nucleus, nuc nucleolus, ooc oocytes, ov ovary, $o v c$ follicle cell, $p$ peritoneum (mesodermal origin), $s p$ sperm, $y d$ yolk droplets

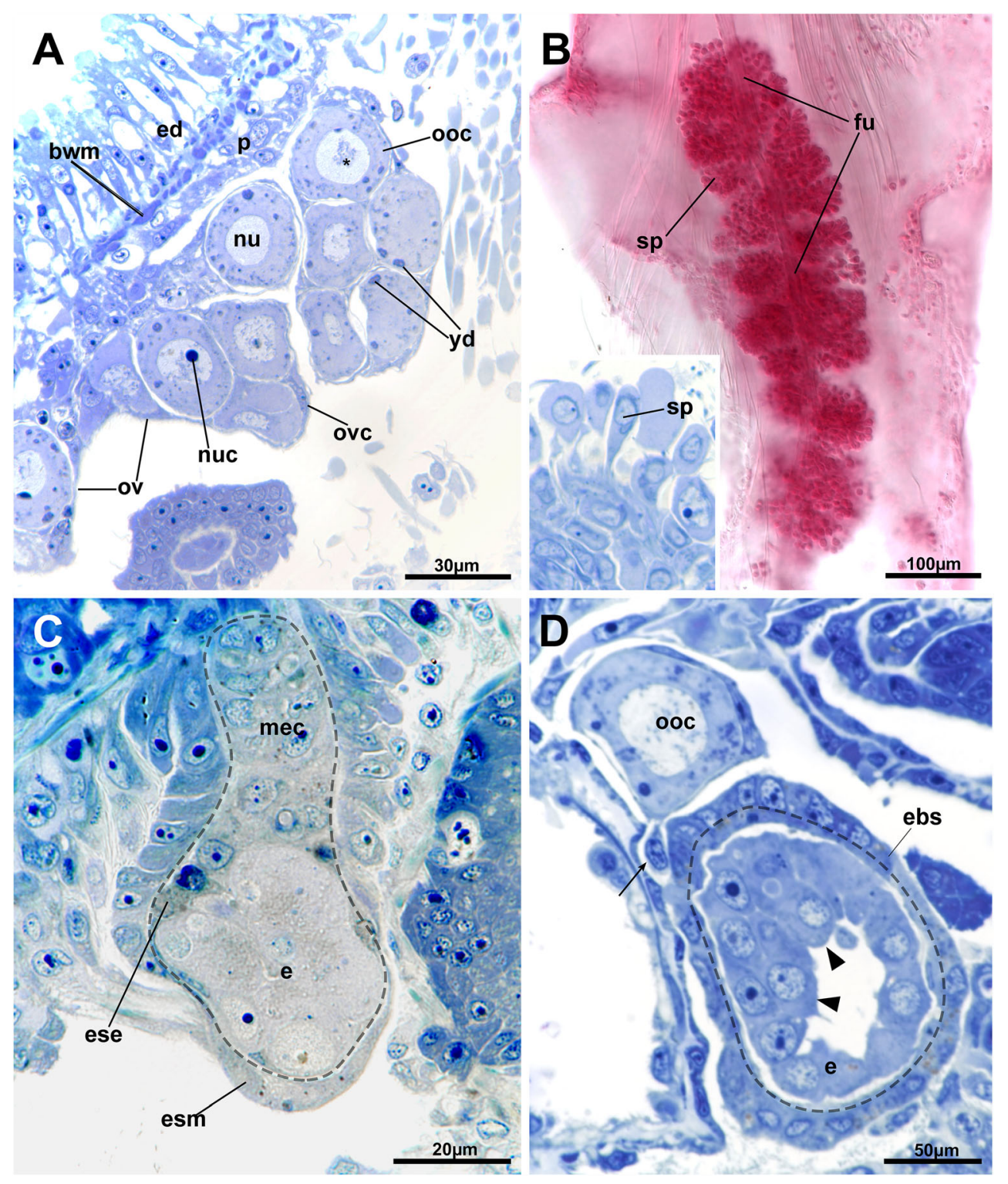

Occasional dividing nuclei were encountered (Figs. 4c, d, 5, 10, 11, 12).

During mesoderm formation, the ectodermal lining of the embryo sac has disappeared at the proximal end. Cytoplasmic extensions of the blastomeres towards the mesoderm and the remaining ectoderm of the embryo sac are present in this developmental stage (Figs. $5 \mathrm{~d}, 7 \mathrm{a}-\mathrm{c}, 10 \mathrm{~b}, \mathrm{c}$ ). Some of these blastomeres are tightly adjoined to the maternal cells, although a direct cell-cell contact was not always found. The cytoplasmatic extensions appear more abundant in the proximal part of the embryo sac. In its distal part, less intensely stained cells of the maternal ectoderm show projections towards the embryo (Fig. 10d). In early stages, densely stained cytoplasmatic inclusions are present in cells of both layers of the embryo sac (Fig. 5c, d). Occasional coelomocytes are located adjacent to the embryo sac (Fig. 11a).

\section{Mesoderm formation}

The upper area of the embryo facing the maternal ectodermal cells at the attachment site of the embryo sac is referred to as posterior pole owing to the swimming direction of the fully developed larva. The opposite pole, at the proximal end of the embryo sac, is referred to as anterior pole. Mesoderm formation starts at the posterior pole of the embryo with dividing blastomeres of the blastula to form an internal layer via delamination (Figs. 4d, 8b, 9c, 10d). This process gradually proceeds from the posterior pole of the embryo towards the anterior one (Fig. 8c). After mesoderm formation, the embryo is distinctly larger, elongated and bilayered (Table 2). At the posterior pole, the mesoderm is composed of cubic cells, whereas they are flattened in the anterior pole (Figs. 9d, 11b, 12). 


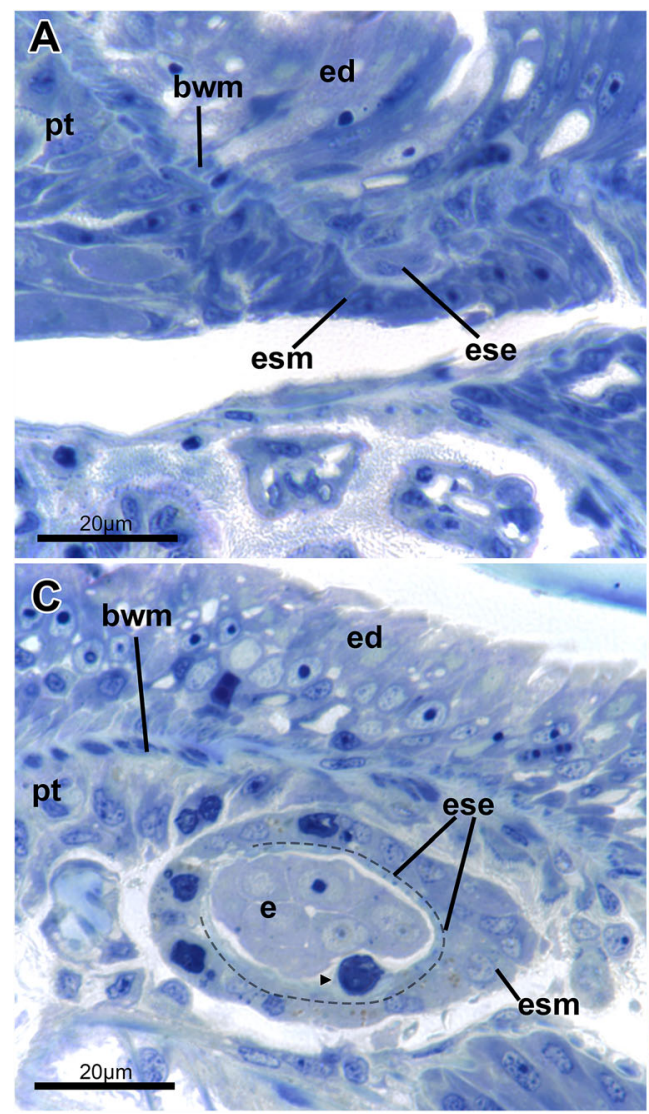

Fig. 5 Early embryo sacs of Plumatella casmiana, semithin sections. The border of the ectodermal and mesodermal layer of the embryo sac are shown by a dashed line in $\mathrm{c}$ and $\mathrm{d}$. a Attachment site of the sac to the cystid wall, which is composed of the epidermis and the peritoneal lining. b Oblique section of the central mass of ectodermal cells plugging the distal area of the embryo sac. c Cross-section of an embryo sac with a blastula stage embryo. Intensely stained cytoplasmic inclusions

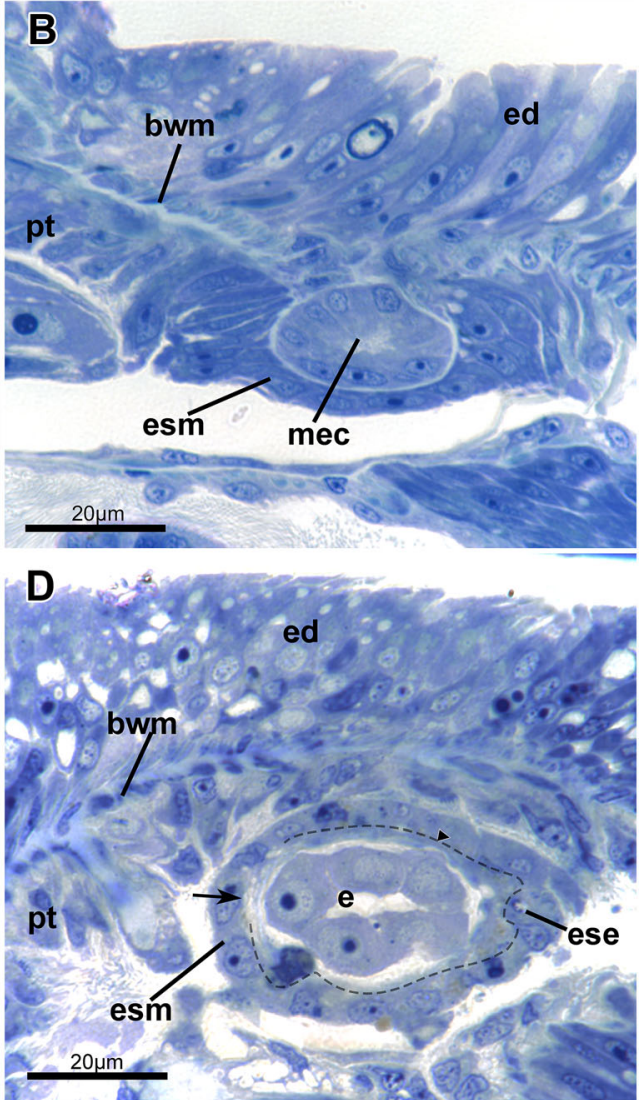

(arrowhead) are present in the embryo sac ectoderm and mesoderm. d Cross-section close to the proximal end of the embryo sac. The embryo adjoins the embryo sac (arrowhead). The ectodermal lining of the embryo sac is being reduced (arrow) from its suspended end. Abbreviations: $b w m$ body wall musculature, $e$ embryo, $e d$ epidermis (ectodermal origin), ese embryo sac ectoderm, esm embryo sac mesoderm, mec maternal ectoderm cells, $p t$ peritoneum (mesodermal origin)
At this stage, the ectodermal lining of the embryo sac is degenerating but remains as thin area at the posterior pole of the embryo (Figs. 8c, 11a-c, 12a, b). The mesodermal layer of the embryo sac is unaltered compared with the previous stage. Some cells remain in close association with the embryo at the anterior pole (Figs. 8c, $11 \mathrm{~d}-\mathrm{f})$.

\section{Formation of polypide buds}

At the end of mesoderm formation, both layers of the bilayered embryo start to proliferate and ingress on the posterior pole, indicating the first signs of bud formation (Figs. 6a, $\mathrm{c}, \mathrm{d}, 8 \mathrm{~d}, 13)$. The ectodermal cells of the embryo show cell divisions and together with the proliferating mesoderm
Table 2 Dimensions of oocytes and embryos of developmental stages of Plumatella casmiana, including volumes from earliest and oldest reconstructed datasets indicating a $37.13 \mathrm{x}$ volume increase

\begin{tabular}{ll}
\hline Stage & Size \\
\hline Mature oocytes & $\sim 40 \mu \mathrm{m}$ diameter \\
Early embryo & $37.6 \mu \mathrm{m}$ diameter \\
Blastula & $42 \mu \mathrm{m}$ \\
Early mesoderm formation & $70 \times 63 \mu \mathrm{m}$ \\
Late mesoderm formation/bud formation & $110 \times 70 \mu \mathrm{m}$ \\
Volumes from reconstructed 3D datasets & \\
$\quad$ Very early embryo: $76795.67 \mu \mathrm{m}^{3}$ & Almost complete larva: $2,865,461.73 \mu \mathrm{m}^{3}$ \\
\hline
\end{tabular}


Fig. 6 Late embryo of Plumatella casmiana, longitudinal section. a Overview of the large thin-walled embryo sac next to the ovary with mature oocytes. The embryo occupies almost the entire cavity of the brood sac and has started to form buds in its distal region. b Ectodermal cells (asterisks) of the posterior pole of the embryo are in direct contact to the maternal ectodermal cells of the embryo sac. c Early bud formation. Ectodermal cells proliferate (arrows) and ingress, while the adjoining mesoderm thickens and surrounds the ectodermal ingression. d Establishment of contact between the embryonic ectoderm (asterisk) and the mesodermal layer of the embryo sac. The border between the ectodermal and mesodermal layer of the embryo sac is shown by a dashed line in $\mathrm{b}$ and c. Abbreviations: ebs embryo sac, eme embryonic ectoderm, emm embryonic mesoderm, mec maternal ectoderm cells

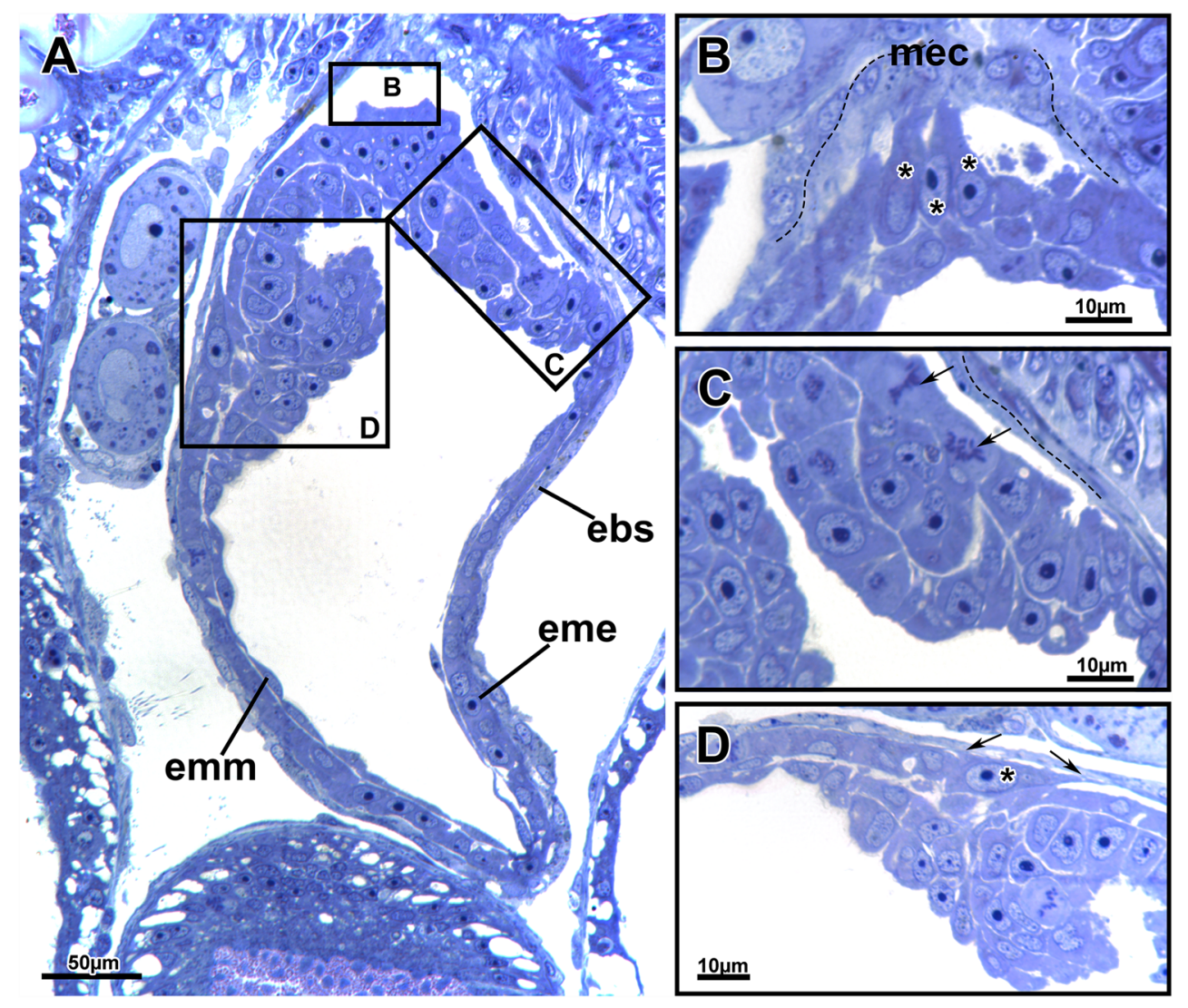

protrude into the coelomic cavity of the embryo (Figs. 6c, d, 13a-d). A second bud forms next to the first one, resulting in two developing zooids within the embryo (Figs. 6, 14).

The ectodermal lining of the embryo sac remains at the posterior pole of the embryo up to the level of bud formation (Fig. 6b, c). At the anterior pole of the embryo, cytoplasmic extensions of its ectodermal cells form contact with the mesodermal cells of the embryo sac (Fig. 11d-f).

\section{Late developmental stages}

Later stages show an increase in size of the embryo and the embryo sac. A comparison of the volume of the early reconstructed embryo (few cells) vs. the latest (almost fully formed larva) showed an increase of $37 \mathrm{x}$ in volume (Table 2). Both buds grow and differentiate within the forming larva (Figs. 8, $14,15,16)$. The cells show no mitotic activity in later stages, and the embryo sac enlarges by flattening and elongation of its cells (Figs. 15, 16). However, some mesodermal embryo sac cells in the proximal area remain voluminous (Figs.15, 16a, b). The ectoderm of the embryo sac persists as few cells at its distal end (Fig. 8e). The epithelia of the anterior hemisphere of late embryos, which were not involved in polypide formation, thicken (Figs. 8e, 15, 16a-d) and start to form the prospective mantle of the larva. On the other side, the epithelia of the posterior side enlarge to form the ancestrular cystid. At the time of mantle differentiation, a ring-shaped contact zone (termed as 'placenta' in previous studies) is established from the cells of the embryo to the adjacent mesoderm of the embryo sac in the posterior half of the embryo (Figs. 6a, D, 8e, 16). Additional, individual ectodermal cells of the embryo form cytoplasmic extensions to the maternal ectodermal cells in the posterior pole (Figs. 6b, 7d).

Slightly below the ring-shaped contact zone of the embryo, the body wall of the developing larva folds inwards and forms an annular groove (Figs. 8c, 14c, 15a, 16a, b). The proximal lining of this groove represents the mantle fold, which subsequently will enlarge and grow in posterior direction, ultimately growing over and disrupting the ring-shaped contact zone. In fully formed larvae, the mantle extends over the entire length and only leaves a small larval aperture at the posterior pole (Fig. 15b). The fully formed larva has doubled in size compared with the stage of initial bud formation (see Table 2) and consists of a ciliated mantle and two enclosed ancestrular zooids.

\section{Contacts between embryo and embryo sac}

There are several contact zones between embryo and embryo sac during development. A close apposition of the embryo to the embryo sac is already present in the earliest observed stages (Figs. 4c; 5c, d) and persists until later bilayered 
Fig. 7 Contact areas of embryos of Plumatella casmiana and the maternal ectoderm. Semithin sections. The border between the ectodermal and mesodermal layer of the embryo sac are shown by the dashed line in a-c. a Blastula stage in a bilayered embryo sac. The latter consists of a thick (outer) mesoderm and a thin inner lining of maternal ectoderm. One blastomere of the embryo is in contact (arrow) with the adjacent ectodermal cell of the embryo sac. The cytoplasm of the connected maternal ectoderm cell stains less intense than adjoining cells. $\mathbf{b}$ Detail of the embryo sac with a maternal ectodermal cell (arrow) in contact with the blastomere. c Detail of a blastula showing contact of a blastomere with the maternal ectoderm in the proximal area of the embryo sac. $\mathbf{d}$ Late embryo showing several ectodermal cells at the posterior pole of the embryo forming contact with the remaining maternal ectodermal cells (arrow). Abbreviations: $e$ embryo, ebs embryo sac, eme embryonic ectoderm, emm embryonic mesoderm, mec maternal ectoderm cells, $o v$ ovary
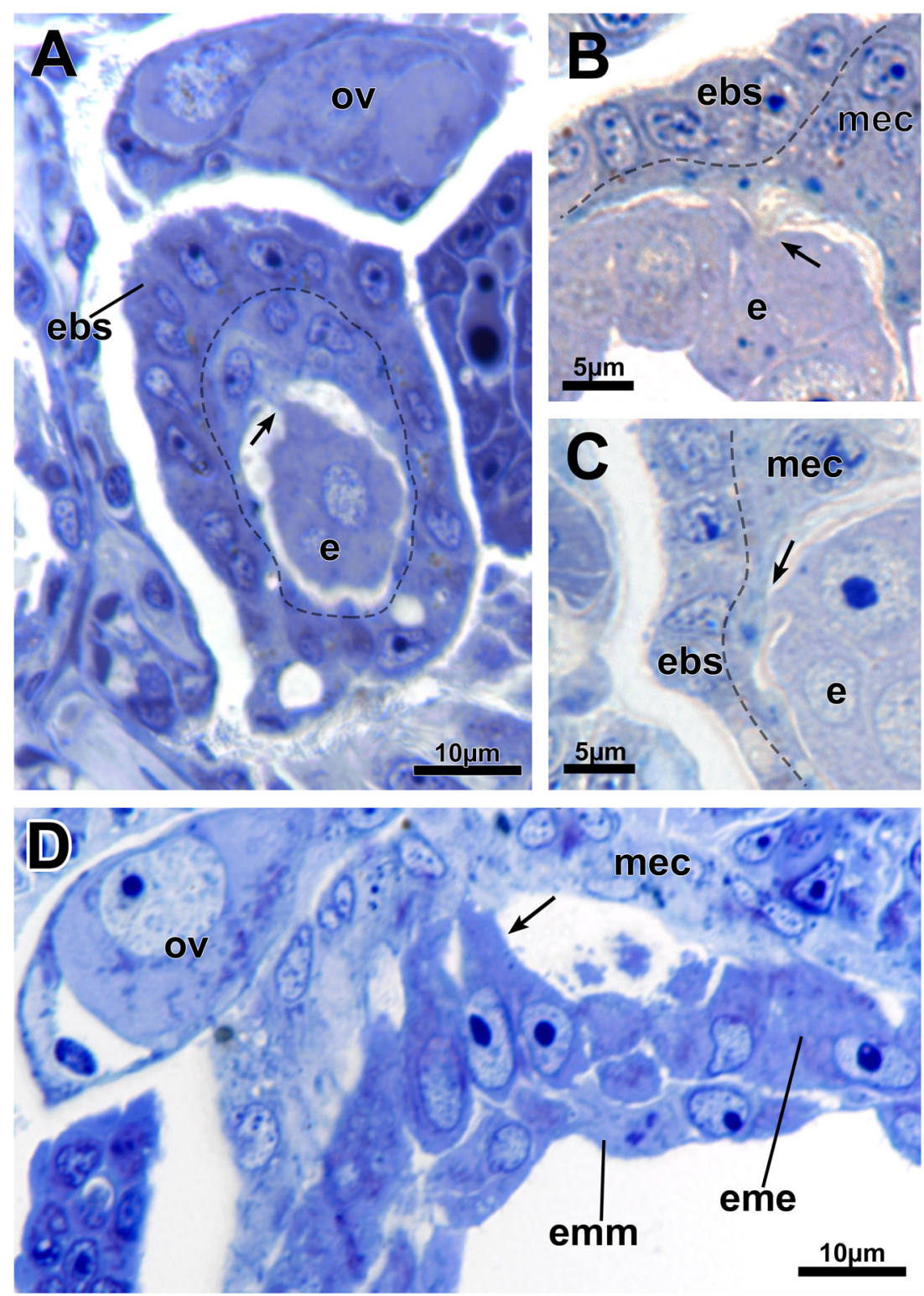

embryonic stages (Figs. 4d, 10b-d, 12b-d). Direct contact between the ectoderm of the embryo sac and the embryo via individual cytoplasmic extensions of the embryonic cells starts to form from blastula stages onwards (Figs. 5d, 7a, c, 10b, 11a, b). Also, cytoplasmic extensions are formed by ectodermal cells of the embryo sac towards the embryo (Figs. $7 \mathrm{~b}, 10 \mathrm{~d})$. Both types of connections are predominantly found in the distal part of the embryo sac. Since the ectodermal lining disappears from the proximal side of the embryo sac, the contacts between the two ectodermal layers ultimately get restricted to the posterior pole of the embryo where cytoplasmic extensions to the maternal ectodermal cells of the embryo sac form during later embryogenesis (Figs. 6b, 7d, 8d). Irrespective of the developmental stage of the embryo, maternal ectodermal cells in contact with the embryo possess a smaller nucleus and nucleolus when compared with embryonic cells. Regardless of the contact type, the cytoplasm of individual contact cells of the embryo sac commonly stains less intense than surrounding cells (Figs. 7a, b, 10d). Besides such ectodermal contacts, similar connections are established between early embryos (and also later stages) and the mesoderm of the embryo sac (Figs. 8c-e, 10c, 11d-f, 12D). Both, the ectoderm of the embryo and the mesoderm of the embryo sac, form cytoplasmic extensions (Fig. 11d-f).

Initially, contacts are not restricted to certain regions of the embryo but appear randomly distributed almost over the entire embryo. The mantle epithelium never shows contacts to the embryo sac. Once it has started to form, the contact areas are restricted to the posterior half of the embryo, most notably in the ring-shaped contact zone of later stages ('placenta'). There are either individual embryonic cells (Figs. 16c, e, f), or clusters of such that form the contact area by cytoplasmatic 


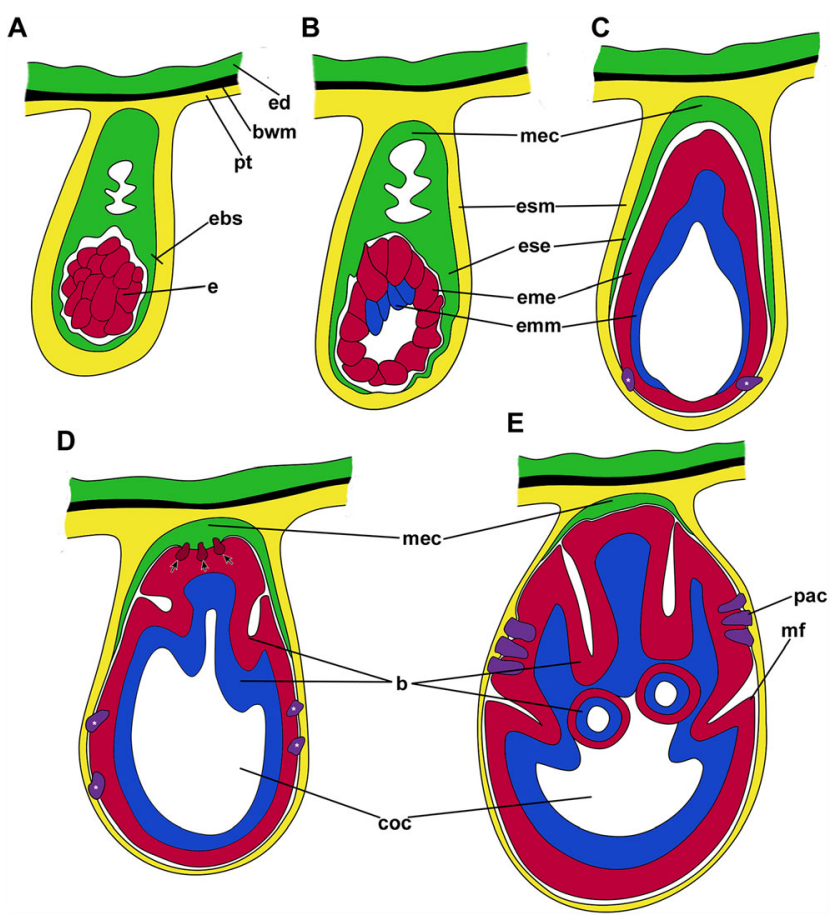

Fig. 8 Schematic drawings of the embryonic development of Plumatella casmiana. a Blastula stage situated at the suspended end of the embryo sac which consists of an external mesodermal layer and an ectodermal part inside that entirely surrounds the embryo at this stage. b Early mesoderm formation from ectodermal cells (red) of the prospective aboral pole of the embryo. Maternal ectoderm in the proximal, suspended end has started to diminish in this stage. c Progressed mesoderm formation showing its progression from the upper attached site towards the suspended, lower area of the embryo sac. The mesoderm of the embryo sac is connected to the embryonic ectoderm via contact cells where the ectodermal lining is reduced. $\mathbf{d}$ Late embryo with commencing bud formation at the aboral pole. The maternal ectoderm is in contact with some embryonic ectodermal cells (arrows). The mesoderm of the embryo sac is connected to the embryonic ectoderm via contact cells. e Late embryo with mantle fold formation. A distinct ring-shaped contact zone has formed at this stage. Abbreviations: $b$ polypide bud, $b w m$ body wall musculature of the maternal cystid, coc coelomic cavity, $e$ embryo, eme embryonic ectoderm, emm embryonic mesoderm, ebs embryo sac, ese ectoderm of embryo sac, esm mesoderm of embryo sac, ed epidermis (ectodermal origin), mec maternal ectoderm cells, $m f$ mantle fold of larval mantle, pac placenta cells, $p t$ peritoneum (mesodermal origin). Colors: peritoneum and mesodermal layer of embryo sac, yellow; epidermis and ectodermal layer layer of embryo sac, green; ectoderm of embryo, red; mesoderm of embryo, blue; contact cells, violet

extensions (Figs. 16b, c, 17a, b). Similar contacts are occasionally formed with the mesodermal cells of the embryo sac. In these areas, the cells of the embryo sac are noticeably larger compared with the remaining thin lining (Fig. 16e, h). These larger cells sometimes stain less intense and can include dark inclusions (Fig. 16f).

The ring-shaped contact zone ('placenta') between embryo and embryo sac develops in the posterior half of the embryo in the proximal area of the ancestrular cystid (Fig. 6a, d). As mentioned above, the mantle fold forming proximally of this contact zone (Fig. 16a, b) will later break through this zone,
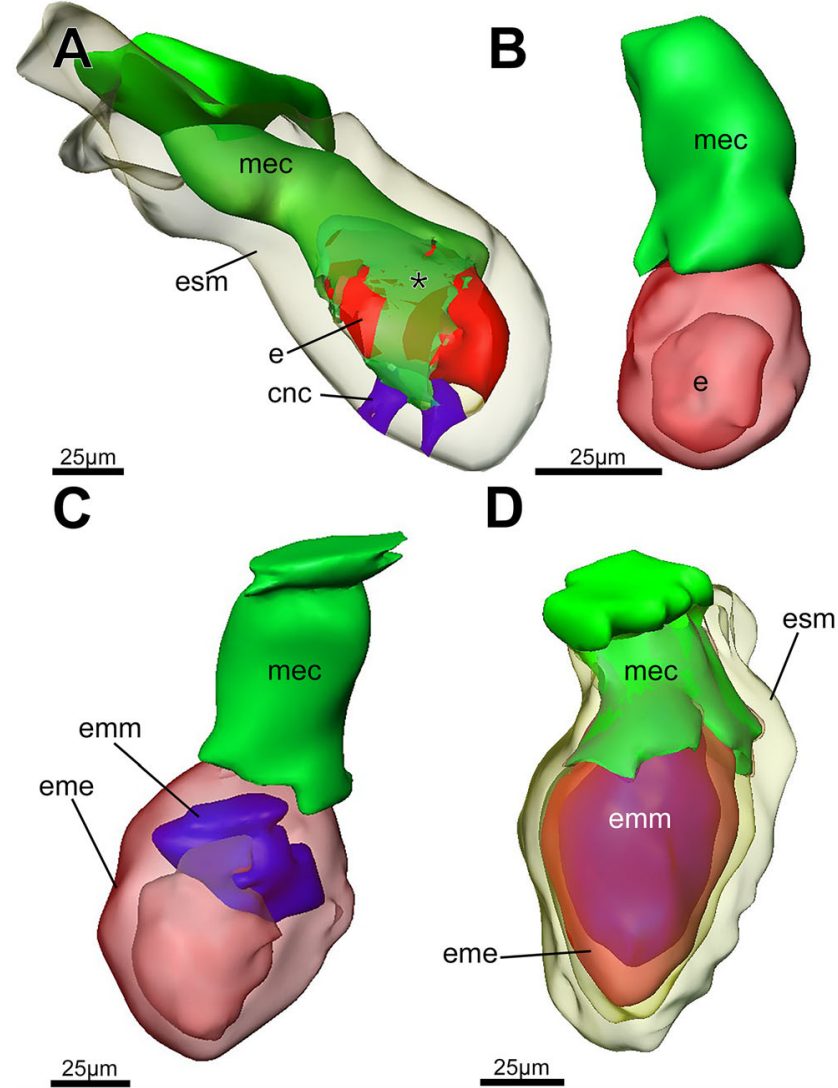

Fig. 9 3D reconstruction of early embryos of Plumatella casmiana based on serial semithin sections. a Embryo consisting of several blastomeres at the suspended end of the bilayered embryo sac. The inner, ectodermal lining of the embryo sac begins to disappear at the suspended end (asterisk). Embryonic contact cells are in connection to the embryo sac. b Blastula with central cavity. The maternal ectoderm cells are now restricted to the contact area towards the body wall. c Early mesoderm formation. d Advanced stage with mesoderm formation completed. Abbreviations: $c n c$ contact cells, $e$ embryo, eme embryonic ectoderm, emm embryonic mesoderm, esm mesoderm of the embryo sac, mec maternal ectoderm cells. Colors: Mesodermal part of embryo sac, yellow; ectodermal part of embryo sac, green; embryonic ectoderm, red; embryonic mesoderm, blue; contact cells, violet

disrupting direct contact between the cells of the embryo and the ES (Fig. 16c, d).

\section{Ultrastructure of contact areas}

The youngest investigated stage by TEM was a bilayered embryo (Figs. 18, 19). The ectoderm cells of the embryo are prismatic or cubic with a large basal nucleus. They contain mostly mitochondria and ribosomes, with few elements of endoplasmatic reticulum and occasional multivesicular bodies (Figs. 18a, b; 19a, c). The apical side of prismatic cells have filiform cytoplasmatic processes between adjacent cells (Fig. 18a), or show regular short processes over the entire surface (Fig. 19a, c). The mesodermal cells of the embryo are smaller and contain mitochondria and ribosomes as well. Some 
Fig. 10 Semithin sections of the embryo sac of Plumatella casmiana. The border between the ectodermal and mesodermal layer of the embryo sac wall are shown by a dashed line in $\mathrm{b}-\mathrm{d}$. a Attachment site of the embryo sac to the body wall showing continuity of its layers with those of the body wall. b Embryo sac with prominent outer mesodermal and thin inner ectodermal layer of (separated by dashed line). Contact cells of blastula-staged embryo are in connection with the ectoderm and mesoderm of the embryo sac (arrowheads). c Longitudinal section showing a cavity lined by the distal maternal ectodermal cells. Contact cells are indicated by arrowhead. d Section of a blastula and its central cavity. Contact cells are apparent in the upper part of the embryo (arrowheads). The epithelial lining of the embryo in this region is thicker and indicates mesoderm formation.

Abbreviations: $b$ polypide bud, $e$ embryo, ed epidermis (ectodermal origin), esm mesoderm of embryo sac, mec maternal ectoderm cells, ov ovary
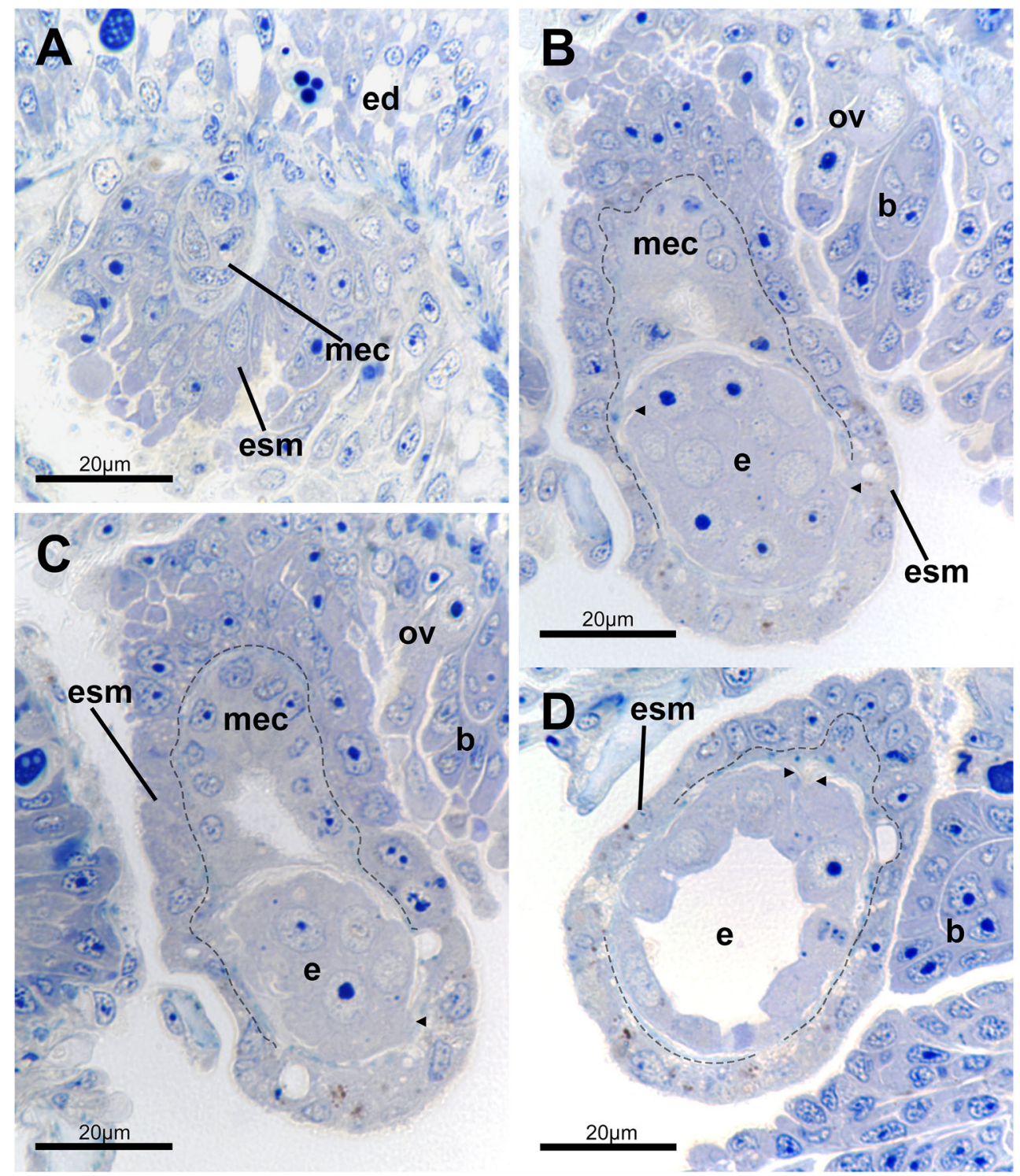

endoplasmatic reticulum is also present (Figs. 18a, c; 19a). In addition, vacuoles of unknown content are found in their apical parts (Fig. 18a, d). Few irregular folds are sometimes present on the apical and basal side of these cells (Fig. 18a, d). The mesodermal cells of the embryo sac contain mitochondria, numerous free ribosomes and large swollen cisterns of endoplasmatic reticulum filled with flocculent material, the same which is present in large vesicles situated close to the apical cell membrane. Some of the vacuoles secrete their contents into the cleft between embryo and embryo sac (Fig. 19a, b). Apart from the vacuoles, the apical side of the cells form thick protrusions, sometimes with vesicles (Fig. 19a) that in some cases were found to interdigitate with processes of the embryo (Fig. 19c, e).

In a more advanced stage, at the onset of bud formation, a close association of the embryonic and maternal tissues remains (Fig. 20). The ectodermal cells of the embryo have numerous cytoplasmic extensions of various shapes and sizes from their apical surface, some approaching the cells of the embryo sac. Cells of the latter also show numerous outgrowths towards the embryo that were thicker than the embryonic ones. The cells show prevalent euchromatin in the nuclei, high amount of endoplasmatic reticulum, some autophagosomes and numerous vesicles of various sizes (Fig. 20). Some of the latter are in open contact with the lumen of the embryo sac to secrete flocculent content (Fig. 20a, c, d). The side facing the maternal coelomic cavity shows a high amount of numerous small, pit-like invaginations on the membrane, potentially indicating endocytosis (Fig. 20b, e). The cytoplasm close to these vesicle formations contains numerous vesicles of various sizes, mitochondria and large multivesicular bodies (Fig. 20c, e). 
Fig. 11 Bilayered embryo of Plumatella casmiana at the beginning of bud formation. Semithin sections. The border between the ectodermal and mesodermal layer of the embryo sac are shown by the dashed line in b \& c. a Double-layered embryo with fully formed mesoderm. Towards the proximal, suspended end of the sac, the mesodermal cells of the embryo are thinner. At one point the embryo sac shows a perforation through which the embryo protrudes (arrow). b Same embryo as in a but a more median section of the embryo and the embryo sac showing mesoderm thickness. Note also the much smaller plug of maternal ectodermal cells towards the body wall. $\mathbf{c}$ Detail of the distal end of the embryo sac showing less staining of ectodermal embryo sac cells compared to the remaining cells. $\mathbf{d}-\mathbf{f}$ Details of contact areas between embryo and embryo sac. Individual cells of the embryonic ectoderm show cytoplasmic extensions (arrows) towards the embryo sac. The mesoderm of the embryo sac projects toward the embryonic ectoderm (d, left arrow). Abbreviations: $b$ polypide bud, clc coelomocyte, eme embryonic ectoderm, emm embryonic mesoderm, ebs embryo sac, mec maternal ectoderm cells, ov ovary

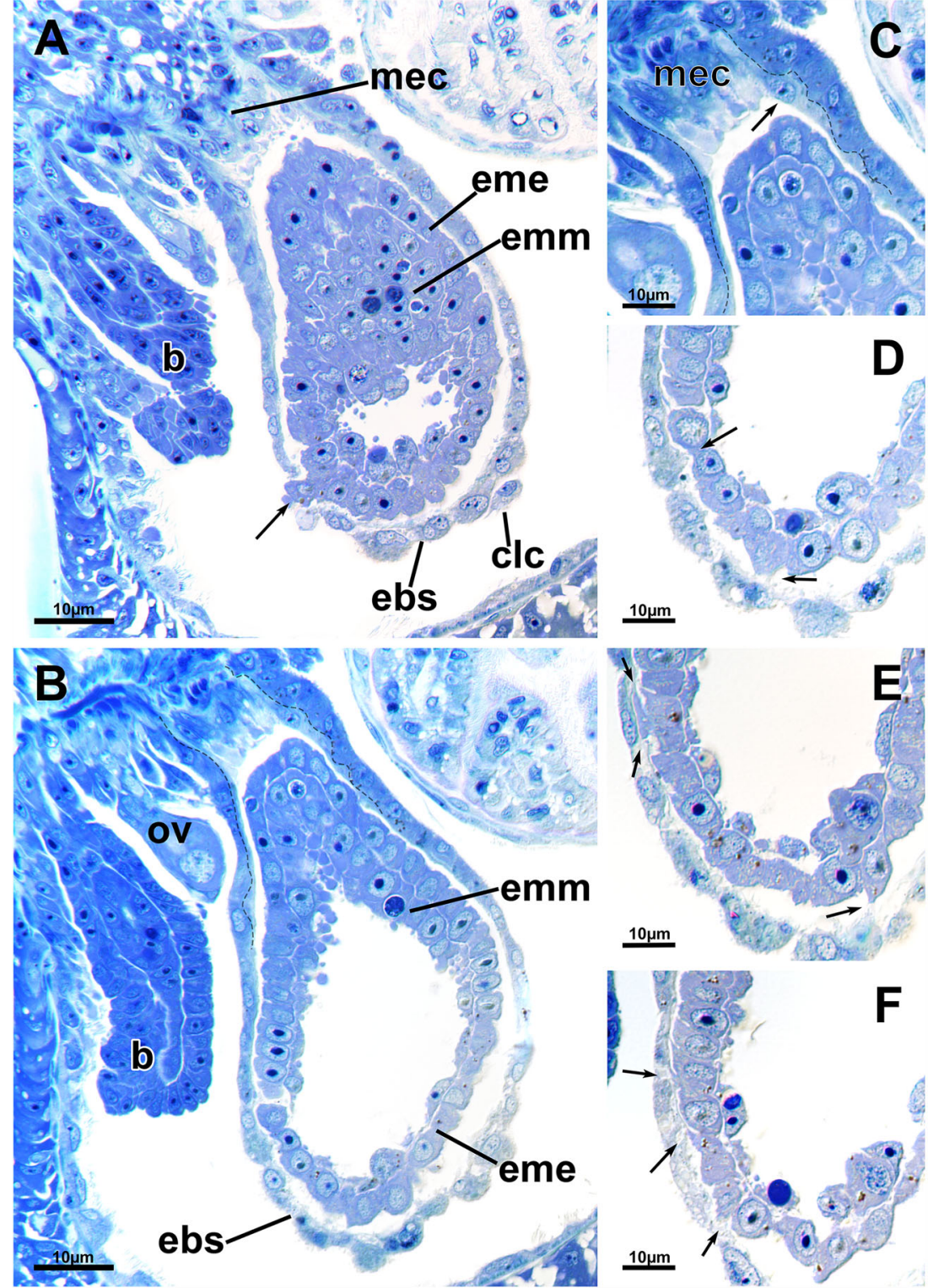

\section{Discussion}

\section{Gametes, fertilization and zygote transfer}

In the studied phylactolaemates, early female germ cells differentiate from the peritoneal layer (Metschnikoff 1871; Korotneff 1890; Davenport 1891; Kraepelin 1892; Braem 1897, 1908b). At first, they are not distinguishable from other peritoneal cells until their nucleus enlarges and nucleoli become visible when differentiating into oogonia (Brien 1953). These grow to a cluster of oocytes with the oldest being closest to the proximal, suspended part of the developing embryo sac. The oocytes are surrounded by flattened follicle cells that together form the ovary (Reinhard 1881; Kraepelin 1892; Braem 1897; Mukai 1982). Whether a complete follicular envelope is present around each oocyte (as indicated from our sections) requires additional TEM analysis but was at least reported absent in Asajirella gelatinosa (Tazima et al. 1984). In addition, nurse-cells were reported being associated with growing oocytes in Lophopus crystallinus (Marcus 1934).

As oocytes mature, the ovary protrudes into the zooidal coelom. Whether young oocytes develop by oogonial divisions or dedifferentiation of peritoneal cells is unknown. Mature oocytes are oligolecithal although numerous yolk granules were found in the cytoplasm of Plumatella evelinae oocytes (Marcus 1941). Oocyte nuclei of P. casmiana have two nucleoli similar to P. fungosa and Asajirella gelatinosa (Reinhard 1881; Braem 1897; Tazima et al. 1984). The cytoplasm appears transparent at early oogenesis, whereas yolk droplets occur mostly on the periphery during oocyte maturation, which coincides with most studied phylactolaemates (e.g. Braem 1897, 1908b; Mukai 1982). Oocyte number and 
Fig. 12 Semithin sections of a bilayered embryo of Plumatella casmiana. The border between the ectodermal and mesodermal layer of the embryo sac wall are highlighted by a dashed line in a, b. a Distal part of the embryo sac and the posterior pole of the embryo. The ectodermal lining of the embryo sac is thin except at its attachment area to the body wall (upper part of image). b Dark cytoplasmic inclusion (arrow) in the mesodermal embryo sac layer. Multiple lipids are visible as light brown inclusions. The embryonic mesoderm consists of flattened cells, and the ectodermal cubic or prismatic cells occasionally show vacuoles (asterisks). In some areas it has tight contact to the dissolving embryo sac ectoderm (arrowhead). c Embryo sac showing voluminous cells of the embryo sac mesoderm (asterisks) and an almost completely reduced ectodermal layer. The ovary is in tight association with the embryo sac with apparent contacts (arrows). $\mathbf{d}$ Ectodermal cell of the embryo showing extension towards the mesoderm of the embryo sac (arrow). Abbreviations: $b$ polypide bud, eme embryonic ectoderm, emm embryonic mesoderm, ese ectoderm of embryo sac, esm mesoderm of embryo sac, mec maternal ectoderm cells, $o v$ ovary

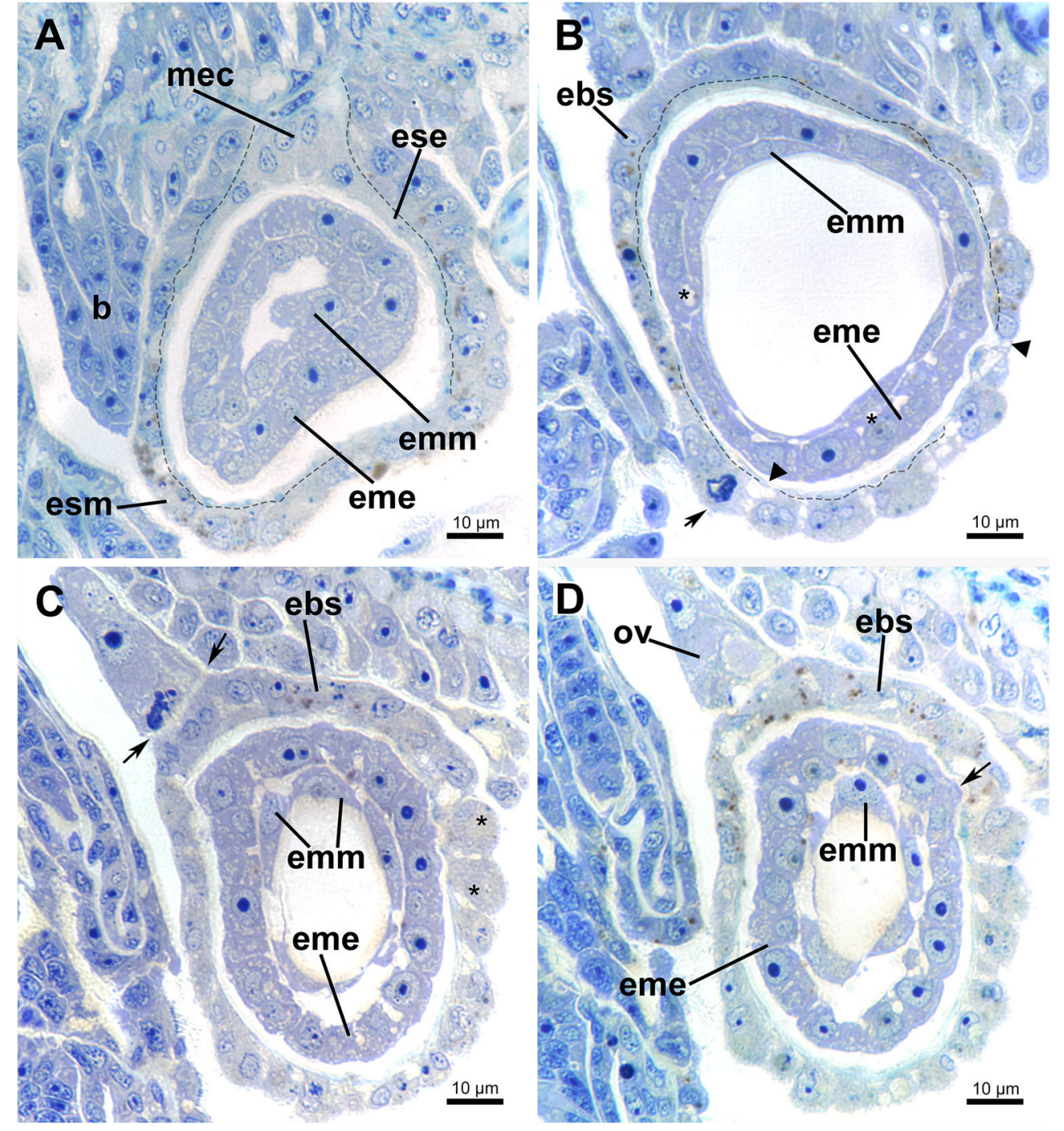

size varies among phylactolaemates: Lophopus crystallinus has up to 42 mature oocytes ( $25 \mu \mathrm{m}$ in diameter) in the ovary including up to 18 reportedly fertilized (Marcus 1934), Asajirella gelatinosa approximately 10 oocytes of $25 \mu \mathrm{m}$ diameter (Oka 1891; Tazima et al. 1984), Cristatella mucedo approximately 10 oocytes of 30-35 $\mu \mathrm{m}$ diameter (Jullien 1890) and Fredericella sultana with a small knotlike ovary in the body wall has 4-6 oocytes of approximately $21 \mu \mathrm{m}$ diameter (Braem 1908b). Among plumatellids, mature oocytes are in the range of $40 \mu \mathrm{m}$ maximum diameter. Their number varies from 8 to 12 in $P$. casmiana (Mukai 1982, this study), 14 in P. evelinae (Marcus 1941) and between 12 (Braem 1897) and 50 in P. fungosa (Brien and Mordant 1955).

Sperm in phylactolaemates was detected as early as in 1839 by van Beneden, and several studies focused on spermatogenesis and sperm structure (see Table 1). The spermatogenic tissue is associated with the funiculus in Plumatella casmiana as in most phylactolaemates (Wood 2014). In most bryozoans, mature sperm leaves the coelom through pores at the tips of the tentacles (e.g. Okamura and Hatton-Ellis 1995; Ostrovsky 2008, 2013b; Ostrovsky and Porter 2011). These pores are known from phylactolaemates (e.g. Marcus 1934, 1941), but whether they are used for sperm release has not been confirmed. Release of mature sperm was detected via a vestibular pore (Oda 1958; Wiebach 1953), which could also act as route for the sperm from other colonies (Ostrovsky and Porter 2011). Genetic fingerprinting of Cristatella mucedo has shown that outcrossing occurs (Jones et al. 1994; Freeland et al. 2003) although experimental work showed that selffertilization is possible too (Oka and Oda 1948).

Fertilization is internal in Phylactolaemata similar to other bryozoans (Reed 1991; Ostrovsky 2008). We did not find any signs of fertilization in the current study, but sperm had been previously recorded in the ovary of Plumatella (Korotneff 1890; Kraepelin 1892; Braem 1897) and male pronuclei have been found in Lophopus crystallinus oocytes (Marcus 1934). Fertilization has been described to occur in the embryo sac 
Fig. 13 Bud formation in an advanced embryo of Plumatella casmiana. Semithin sections. The border between the ectodermal and mesodermal layer of the embryo sac wall are shown by a dashed line in a and d. a, b Different section levels of same embryo showing proliferating cells (arrows in b) of the anlage of the bud, close to the posterior pole of the larva. Buds are two-layered and protrude into the lumen of the embryo. c, d. Two-layered polypide anlage (asterisk) consisting of an inner (epidermal/ectodermal) and outer (peritoneal/mesodermal) budding layer. Abbreviations: ebs embryo sac, eme embryonic ectoderm, emm embryonic mesoderm

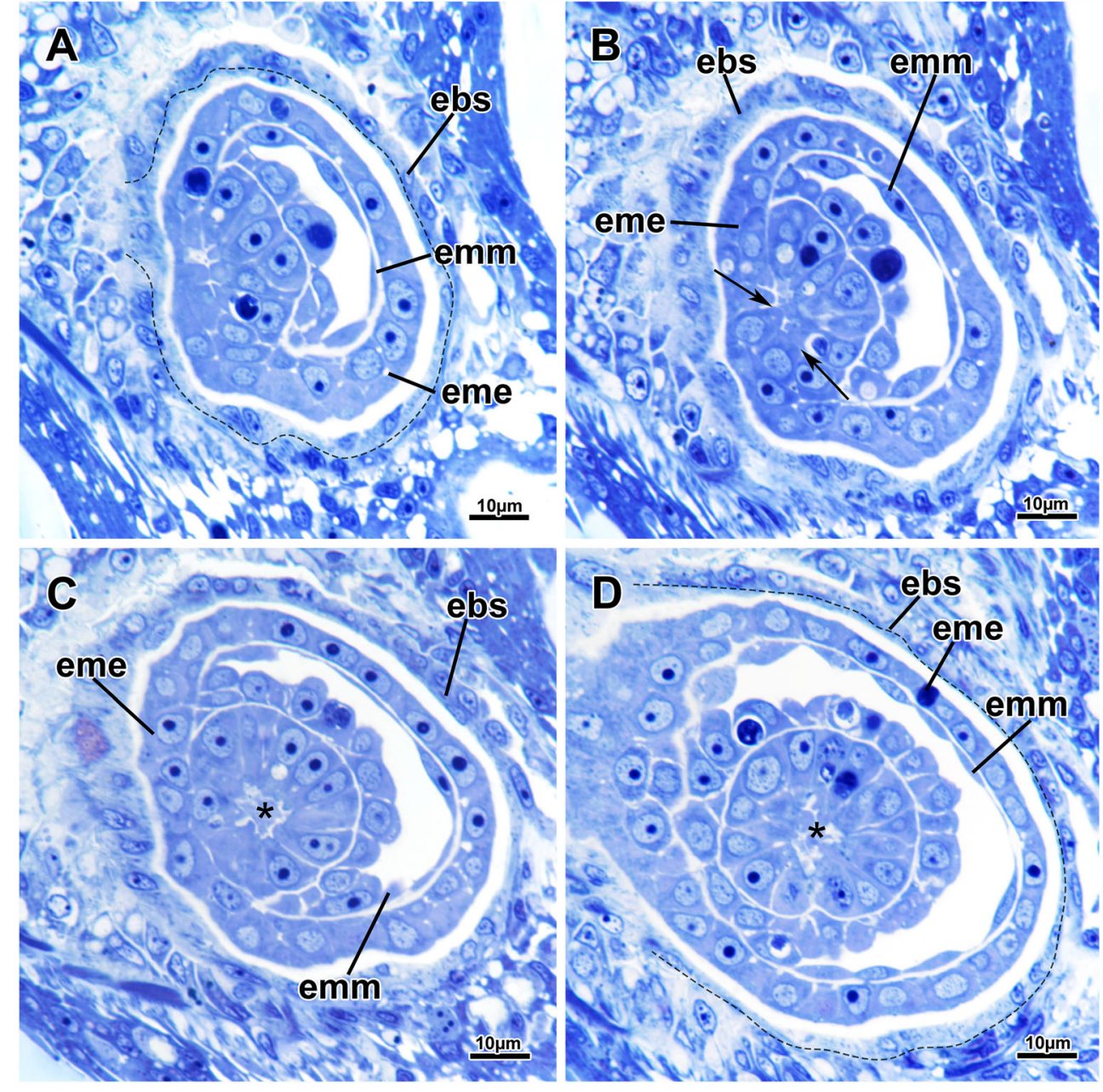

(Marcus 1934) or in the ovary (Korotneff 1890), the latter being present in most and also all other incubating bryozoans (Ostrovsky 2008).

Transfer of the zygote from the ovary into the embryo sac was hypothesized in two ways:

(1) Amoeboid movement of the fertilized oocyte from the ovary into the embryo sac (Korotneff 1890; Brien 1953). This may involve zygotes to be circulated within the body cavity prior to implantation into the embryo sac (Metschnikoff 1871; Marcus 1934). Support for this mode of transfer by the present study is the presence of occasional free oocytes encountered in the body cavity.

(2) Direct transfer by the close apposition of the embryo sac with the ovary. By direct contact of these two tissues, the fertilized oocyte would be subsequently moved into the embryo sac (Braem 1897, 1908b). Although a close association of both structures has been described by other authors and has also been encountered in the present study, their direct apposition has not been confirmed.
In some ctenostome bryozoans, ovulated oocytes are released via a supraneural coelomopore to be attached to the outer body wall and subsequently immersed into a brood sac similar to phylactolaemates (Braem 1951; Ström 1977). This mode was never observed in phylactolaemates, and internal oviposition was considered as ancestral (Silén 1944). There are many issues still requiring additional analyses for clarifying fertilization and the original mode of brooding.

\section{Embryo sac}

The phylactolaemate embryo is incubated within an embryo sac at the cystid wall, contrary to earlier observations stating that a ciliated embryo develops inside the ovary (Allman 1856; Reinhard 1881) because of its monolayered wall (see also Kraepelin 1892; Marcus 1934). Zygotes are incorporated in a double-layered structure, the embryo sac, which is reminiscent of polypide buds. The embryo sac (sometimes termed 'ooecium' in older literature, analogous to a functionally similar structure in marine bryozoans) was accordingly considered as modified polypide bud by some authors (Nitsche 


\section{A}

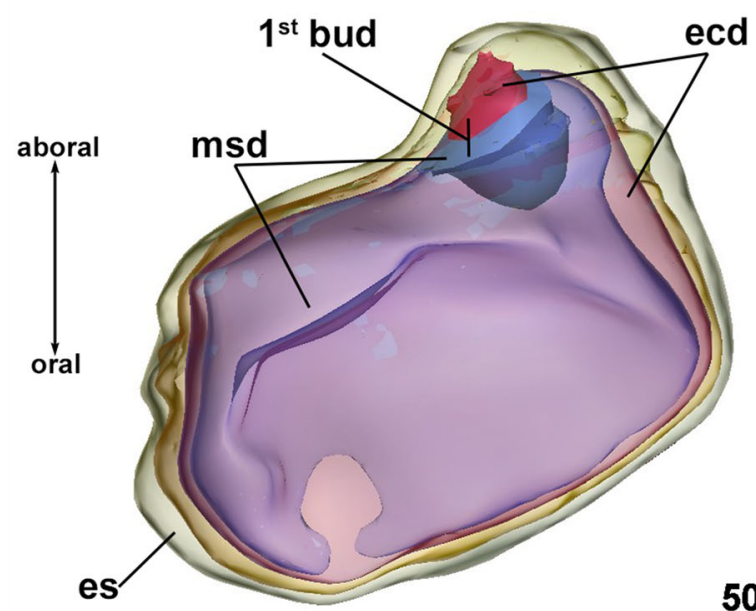

$50 \mu \mathrm{m}$

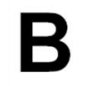

\section{B}

$2^{\text {nd }}$ bud
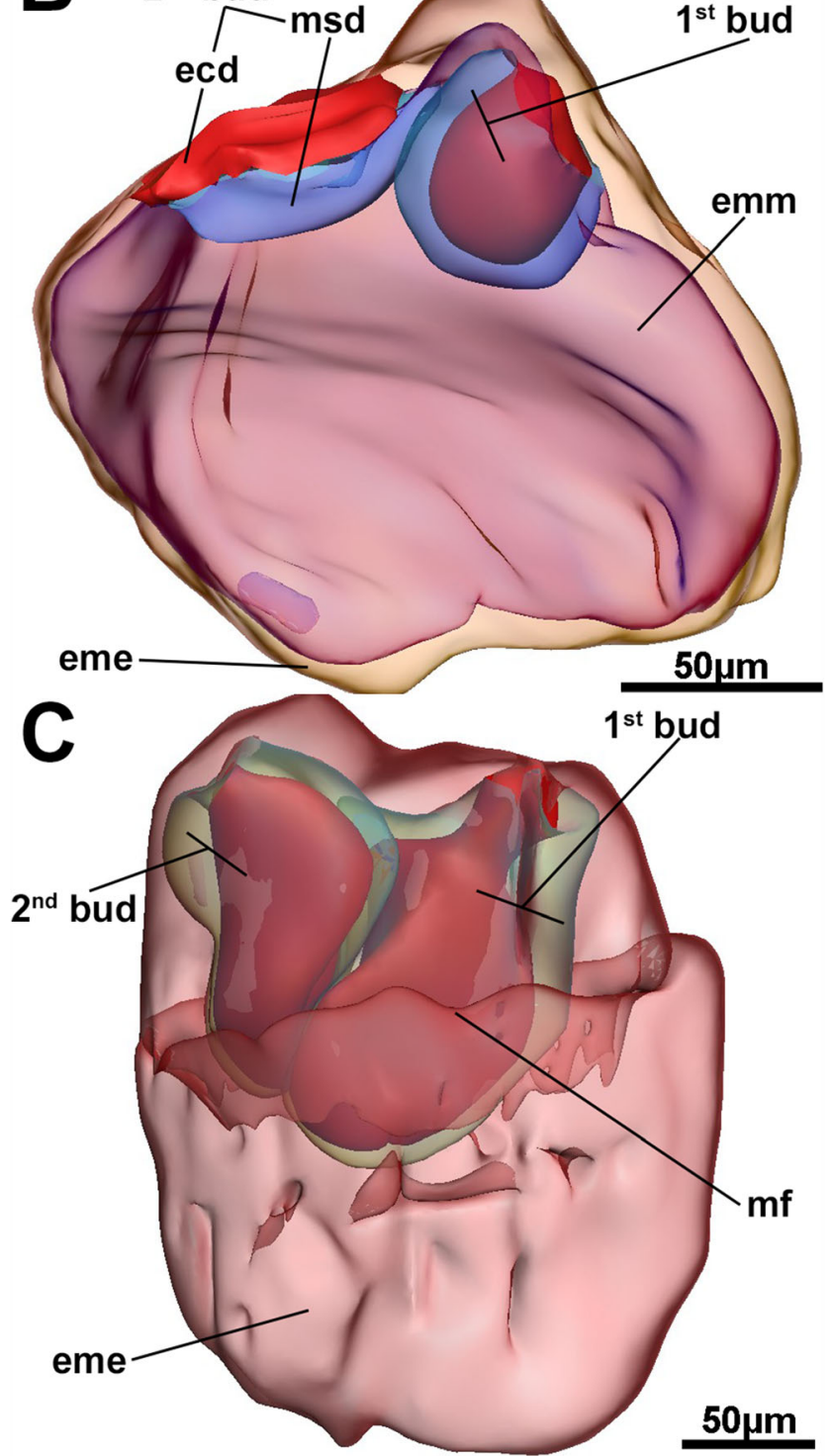

Fig. 14 3D reconstruction of advanced embryos of Plumatella casmiana based on serial semithin sections. a Bilayered embryo within thin embryo sac. The first bud forms from both embryonic layers in the posterior hemisphere. Mesoderm invagination and ectoderm ingression take place simultaneously. b Bilayered embryo with two buds developing next to each other. The first (older) bud is cup-shaped (to the right); the mesoderm of the second bud starts to invaginate and is accompanied by proliferation of the ectoderm. $\mathbf{c}$ Late embryo with both buds protruding from the posterior pole. The first bud is slightly larger than the second one. The mantle fold has formed halfway along the longitudinal axis. Abbreviations: es embryo sac, ecd ectoderm, eme embryonic ectoderm, emm embryonic mesoderm, $m f$ mantle fold, $m s d$ mesoderm. Colors: blue, mesoderm of embryo; red, ectoderm of embryo; yellow, embryo sac

1872; Metschnikoff 1871; Kraepelin 1892; Braem 1897). Alternatively, the embryo sac was considered as independent structure that develops via local thickening of the body wall involving cell enlargement and seemingly proliferation (Korotneff 1887a) which corresponds to the data of Brien $(1936,1953)$ and our data. In contrast, embryo sac formation was also described as invagination of both layers of the cystid wall in P. fungosa and P. casmiana (Mukai 1982). The latter could not be confirmed by our current study. In general, development and formation of the embryo sac after oviposition is similar as previously described (Kraepelin 1892; Braem 1897; Marcus 1934; Brien 1953).

Internal brood sacs formed by non-calcified body walls are widespread among gymnolaemate bryozoans and evolved independently several times in cteno- and cheilostomes (Ostrovsky 2013a; Ostrovsky et al. 2006, 2009a, b). In some species of both clades, these sacs provide extraembryonic nourishment (Ostrovsky et al. 2009c, 2016; Schwaha et al. 2019), similar as found in phylactolaemates. Incubation chambers were considered homologous among the different bryozoan clades, with the phylactolaemate one (referred as 'embryonary') considered ancestral (Silén 1944). The distribution of reproductive patterns (including modes of fertilization, oogenesis and larval types), however, indicates that embryonic incubation, and also internal brood sacs, evolved independently in all large clades (Ostrovsky 2013a). In several ctenostomes, brood sacs are formed as invagination of the body wall that includes a zygote that is attached to the cystid after release by the polypide (Braem 1951). In contrast, brood chamber formation in cheilostomes is supposedly triggered by the development of the ovary (Silén 1945; Ostrovsky and Schäfer 2003). This is similar to phylactolaemates where an embryo sac only forms after the ovary has started to form.

\section{Embryonic development}

Compared with other bryozoans, cleavage in phylactolaemates is generally regarded as derived and little studied. It is holoblastic and irregular and results in a morula 


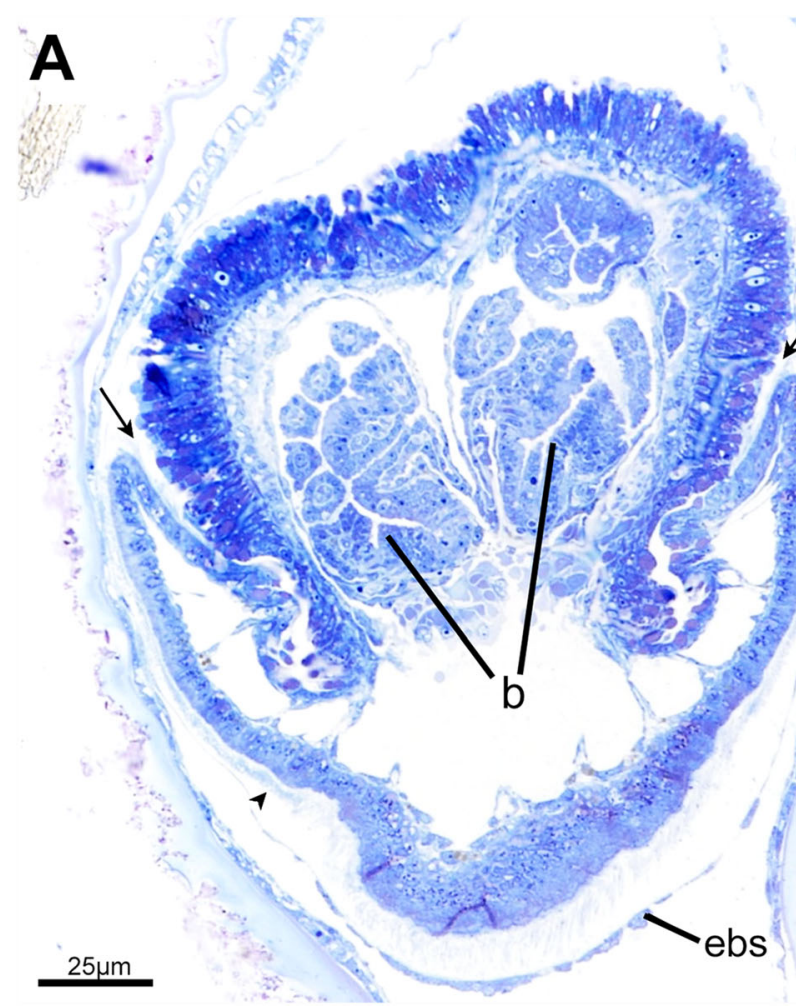

Fig. 15 Longitudinal sections of brooded larvae of Plumatella casmiana. a. The embryo sac is conspicuous. The larval mantle is ciliated (arrowhead) and in earlier stages restricted to the anterior pole of the larva. Halfway along the longitudinal axis the mantle forms a deep groove (arrows). Two almost differentiated buds are present in the larva. b

followed by a hollow blastula (Allman 1856, Metschnikoff 1871; Korotneff 1890; Kraepelin 1886, 1892; Braem 1897, 1908b; Marcus 1934, reviewed in Reed 1991; D'Hondt 2005; Santagata 2015). Development of Plumatella casmiana is similar to previous reports on phylactolaemates, but we found differences concerning the formation of various tissues.

Mesoderm formation in Plumatella fungosa starts approximately between the 20-30 (Brien 1953) or the 30-36 cell stage (Braem 1897), the former number being supported by our data on $P$. casmiana with approximately 30 cells. Its differentiation from the ectoderm starts from the posterior pole of the embryo as previously described (Kraepelin 1892; Braem 1897; Mukai 1982) but occurs via delamination instead of unipolar immigration/ingression of the prospective mesodermal cells into the blastocoel with subsequent alignment to the ectoderm (Korotneff 1887a, b; Davenport 1891; Kraepelin 1892; Braem 1897). Delamination of mesodermal cells occurs along the longitudinal axis of the embryo, from posterior to anterior. An endoderm is absent throughout development, although temporary endodermal cells were described that immigrate into the blastocoel at the posterior pole in P. fungosa (Braem 1897). These short-lived cells were neither found in subsequent studies (Mukai 1982) including the present one. Similar blastocoel-occupying cells were also described in

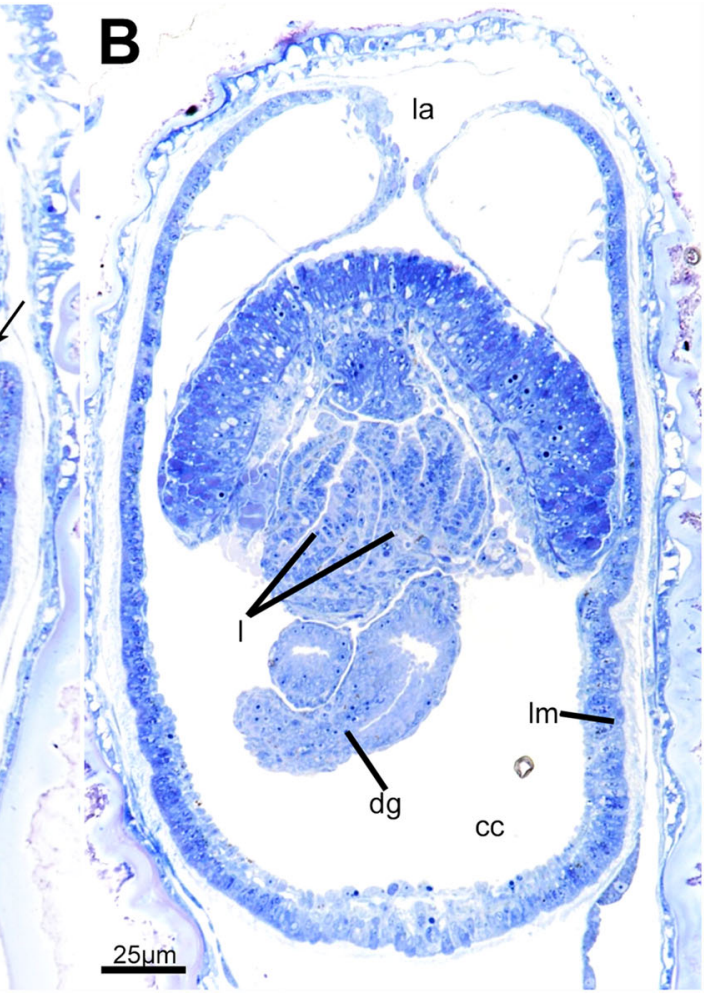

Fully developed larva entirely surrounded by the mantle . The embryo sac is even less pronounced but still contains some larger cells. Abbreviations: $b$ bud, $c c$ coelomic cavity, $d g$ digestive tract, $e b s$ embryo sac, $l a$ larval aperture, $l$ lophophore, $l m$ larval mantle

mesoderm formation that either fill most of the blastocoel (Kraepelin 1892) or divide it into two parts (Braem 1897; Mukai 1982). Similar to the supposed endodermal cells, these could not be verified (Brien 1953, this study).

Most phylactolaeamates, including Plumatella casmiana, possess two polypide buds in the larva. Only Cristatella and Pectinatella have four, whereas Fredericella has only one (Schwaha et al. 2015). In accordance with previous descriptions (e.g. Braem 1897), bud formation starts when mesoderm formation is almost completed. During bud formation in $P$. casmiana, the embryonic ectoderm initially proliferates and ingresses towards the mesoderm, which then invaginates and proliferates as well. This differs from previous descriptions according to which both embryonic tissues simply thicken and fold inwards as in asexually produced buds (Braem 1897).

\section{Embryo-maternal contact}

A contact area between embryo and embryo sac, in form of the ring-shaped contact zone, was recognized by numerous authors and termed 'placenta' (Kraepelin 1886; Korotneff 1890; Braem 1897). This term suggests its nourishing function (Davenport 1891; Brien 1953; Hyman 1959; Mukai 
Fig. 16 Semithin sections of late embryonic stages of Plumatella casmiana. a, b Longitudinal sections of an early larva. The mantle is not yet ciliated and a mantle fold is present in the equatorial region. Posterior of the mantle fold, the ring-shaped contact zone ('placenta') of elongated cells of the larval ectoderm is in contact with the mesoderm of the embryo sac (partly seen in a). The embryo sac is rather thin but still includes voluminous cells (arrowheads), some with cytoplasmatic inclusions (arrows). c, d Oblique cross section of an advanced larva showing contact areas of the larva to the cells of the embryo sac. The ringshaped 'placenta' is disrupted where the mantle fold overgrows the larva in posterior direction. $\mathbf{e}-\mathbf{i}$ Contact cells (asterisks) in early larvae. These cells are either formed by cytoplasmatic extensions of embryonic/larval cells (e, $\mathbf{f})$, or their origin is unclear $(\mathbf{g}, \mathbf{h})$. In some cases they appear to belong to the embryo sac (i). Abbreviations: $b$ bud, $e$ embryo/ larva, ecd ectoderm of the larva, ebs embryo sac, ma larval mantle, $m s d$ mesoderm of the larva, $m f$ mantle fold, pac placenta cells
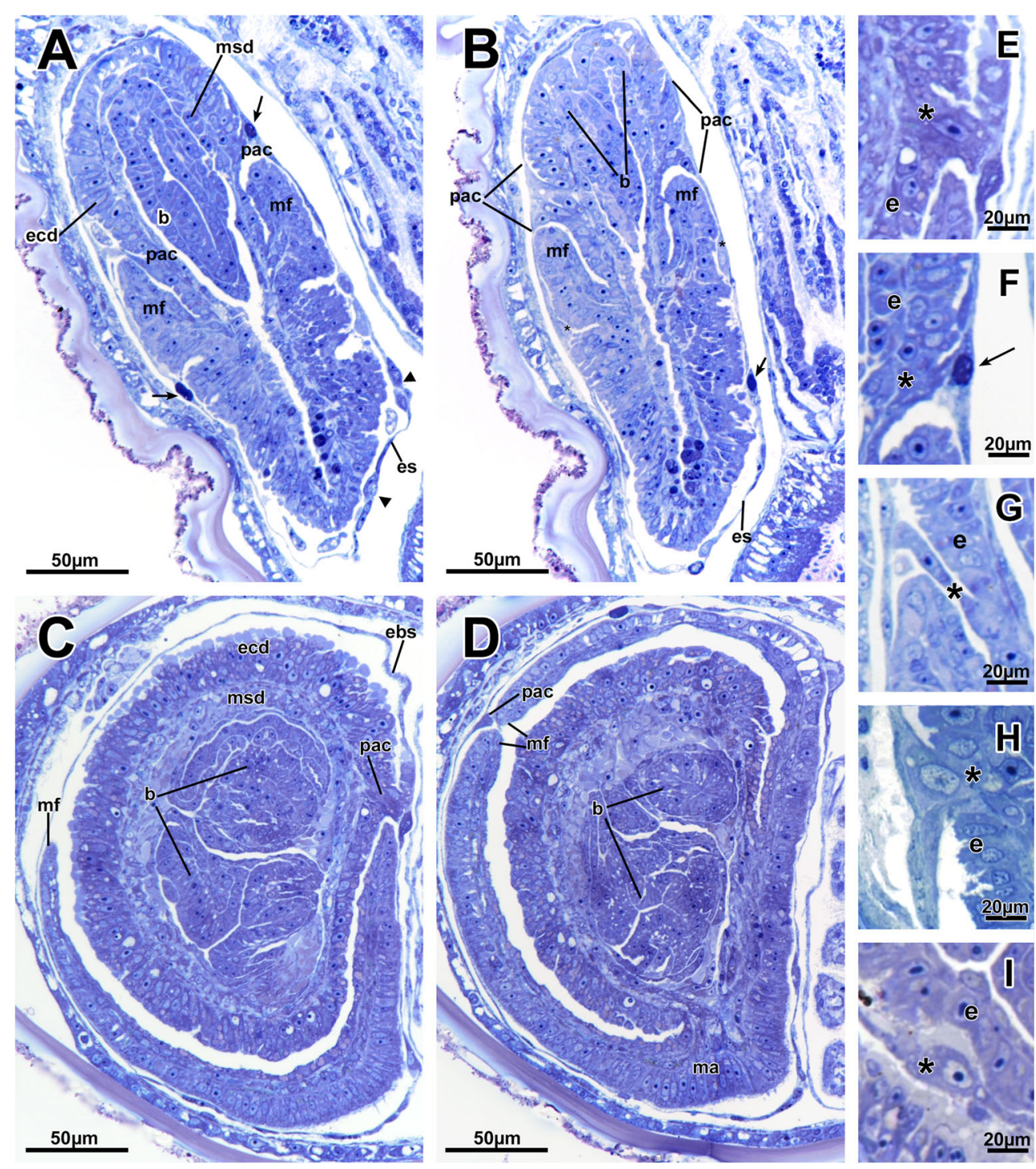

1982), but its function as anchoring structure that holds the embryo in a certain position in the embryo sac was proposed as an alternative scenario (Kraepelin 1892; Braem 1897).

Elongate cylindrical cells, supposedly of embryonic and embryo sac origin, were described to form the placental ring in P. fungosa (Korotneff 1890). Initially, cell contacts to ectodermal cells of the embryo sac are present at the posterior pole that subsequently enlarge and elongate and make contact with the mesodermal cells of the embryo sac (Braem 1897). During further development, the number of embryonic contact cells increases and the placental ring-shaped contact zone forms in the equatorial region of the embryo (see also Kraepelin 1892). Previous studies on P. casmiana reported a cap of embryonic ectodermal cells on the posterior pole that participates in the formation of the placental ring (Mukai 1982), for which no evidence was found in the current study. In Fredericella sultana individual cell contacts were described in posterior and anterior areas of the embryo (Braem 1908b).
The current results on $P$. casmiana show a more complex situation: before the formation of the placental ring, the embryo and the embryo sac establish temporary individual contacts. First indications of such contacts start at the blastula stage when blastomeres form cytoplasmic extensions towards mesodermal and ectodermal cells of the embryo sac. In addition, some cells of the maternal ectoderm form projections towards the embryo in the distal part of the embryo sac (see also Braem 1897). The function of these temporary individual contacts remains unclear. These randomly distributed contact cells are much later replaced by the ring-shaped contact zone (placenta). During early bud formation, embryonic cells at the anterior pole form individual cytoplasmic extensions towards the mesodermal cells of the embryo sac. The latter form similar processes towards the embryo. When the embryo forms the second bud, several neighbouring cells on the posterior pole of the embryo form cytoplasmic extensions towards the maternal ectodermal cells. Such a prominent contact of the 

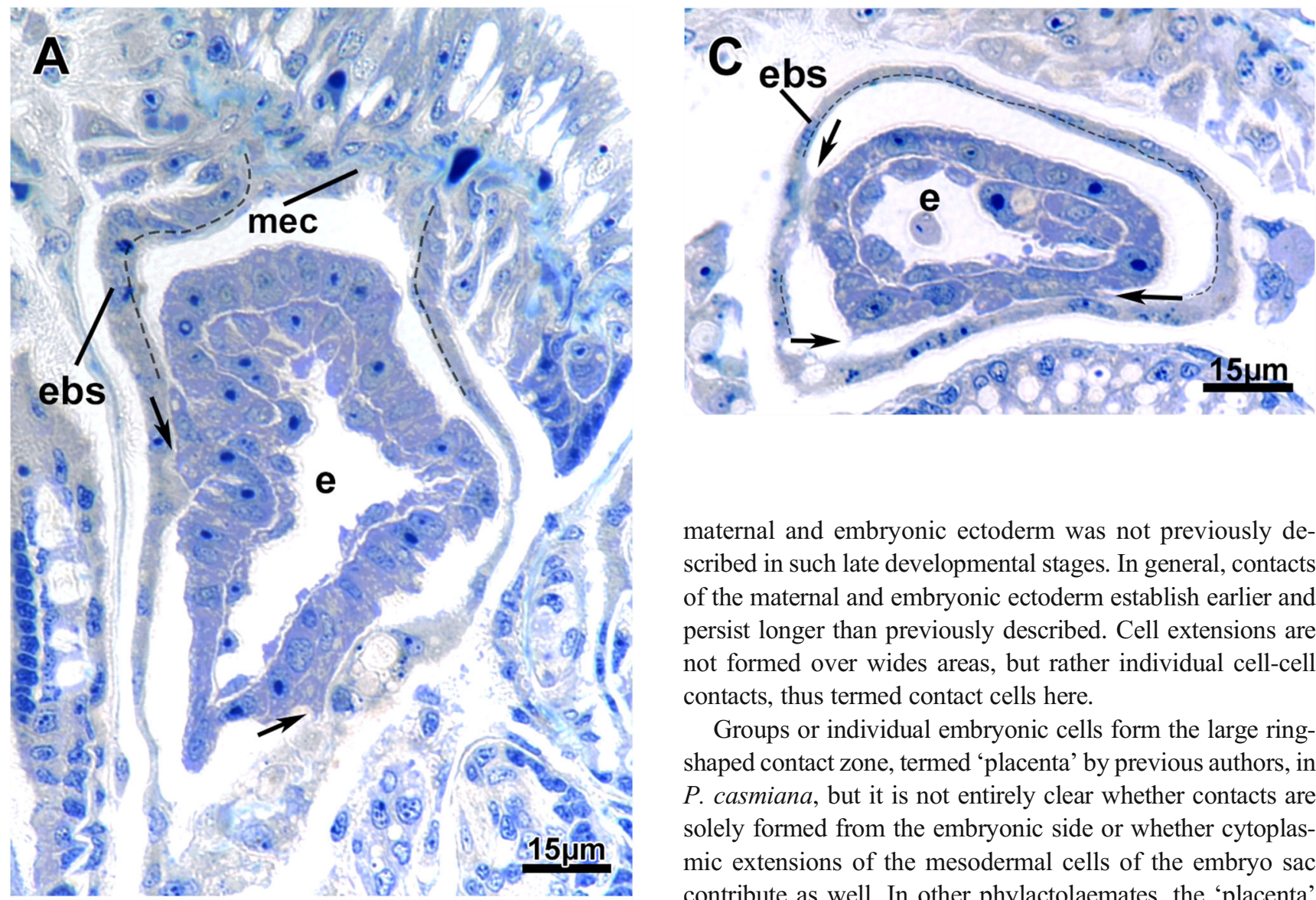

maternal and embryonic ectoderm was not previously described in such late developmental stages. In general, contacts of the maternal and embryonic ectoderm establish earlier and persist longer than previously described. Cell extensions are not formed over wides areas, but rather individual cell-cell contacts, thus termed contact cells here.

Groups or individual embryonic cells form the large ringshaped contact zone, termed 'placenta' by previous authors, in $P$. casmiana, but it is not entirely clear whether contacts are solely formed from the embryonic side or whether cytoplasmic extensions of the mesodermal cells of the embryo sac contribute as well. In other phylactolaemates, the 'placenta' or contact zone was described to consist of both 'fetal' and 'uterine' cells in Fredericella sultana (Braem 1908b). In Cristatella mucedo, the so-called 'placentulum' was also mentioned as fusion of maternal and embryonic cells (Jullien 1890). A nutritive function of the latter was suggested (Davenport 1891, as 'placenta-like neck of the ooecium'). Lophopus crystallinus appears to lack any large contact zone between embryo and embryo sac altogether (Marcus 1934). Although generally similar, reports of these particular contact structures and zones are commonly based on single, and old, observations. It would be necessary to obtain material from several, sexually active colonies of different, families and to apply more recent methods such as used in this study in order to get a better insight into variation, structure and function of these contact zones.

Fig. 17 Contact areas of embryos and embryo sac in Plumatella casmiana, semithin sections. The border between the ectodermal and mesodermal layer of the embryo sac are marked by a dashed line. a, b Establishment of the ring-shaped contact zone of the bilayered embryo by ectodermal cells of the embryo (arrows) that connect to the mesoderm of the embryo sac. Both layers of the embryo are thickened on the posterior side towards the body wall, indicating early bud formation. c, Contact cells forming at random locations in the anterior hemisphere of an early embryo (a, b). Abbreviations: $e$ embryo, ebs embryo sac, mec maternal ectoderm cells 
Fig. 18 Ultrastructure of the anterior hemisphere of a bilayered embryo and embryo sac shortly before bud formation in Plumatella casmiana (TEM). a Overview of embryonic epithelia and embryo sac. The embryo shows high prismatic ectoderm and flattened mesodermal cells. Ectodermal cells possess filiform extensions on their lateral sides. $\mathbf{b}$ Detail of an embryonic ectodermal cell showing filiform processes, mitochondria, numerous free ribosomes and a multivesicular body in the apical part of the cell. $\mathbf{c}$ Detail of a mesodermal cell of the embryo sac. In contrast to the embryonic cells, it shows a lower density of ribosomes, but much more vacuoles and endoplasmatic reticulum. Presumed site of exocytosis towards the lumen of the embryo sac is marked by an arrow. d Detail of the mesoderm of the embryo including large vacuoles with unknown content (asterisks). Arrow shows an extension of the cell membrane towards the basal lamina.

Abbreviations: $b l$ basal lamina, eme embryonic ectoderm, emm embryonic mesoderm, er endoplasmatic reticulum, esm mesoderm of the embryo sac, $m i$ mitochondria, $m v b$ multivesicular body, $n u$ nucleus, nuc nucleolus, $r i$ ribosomes

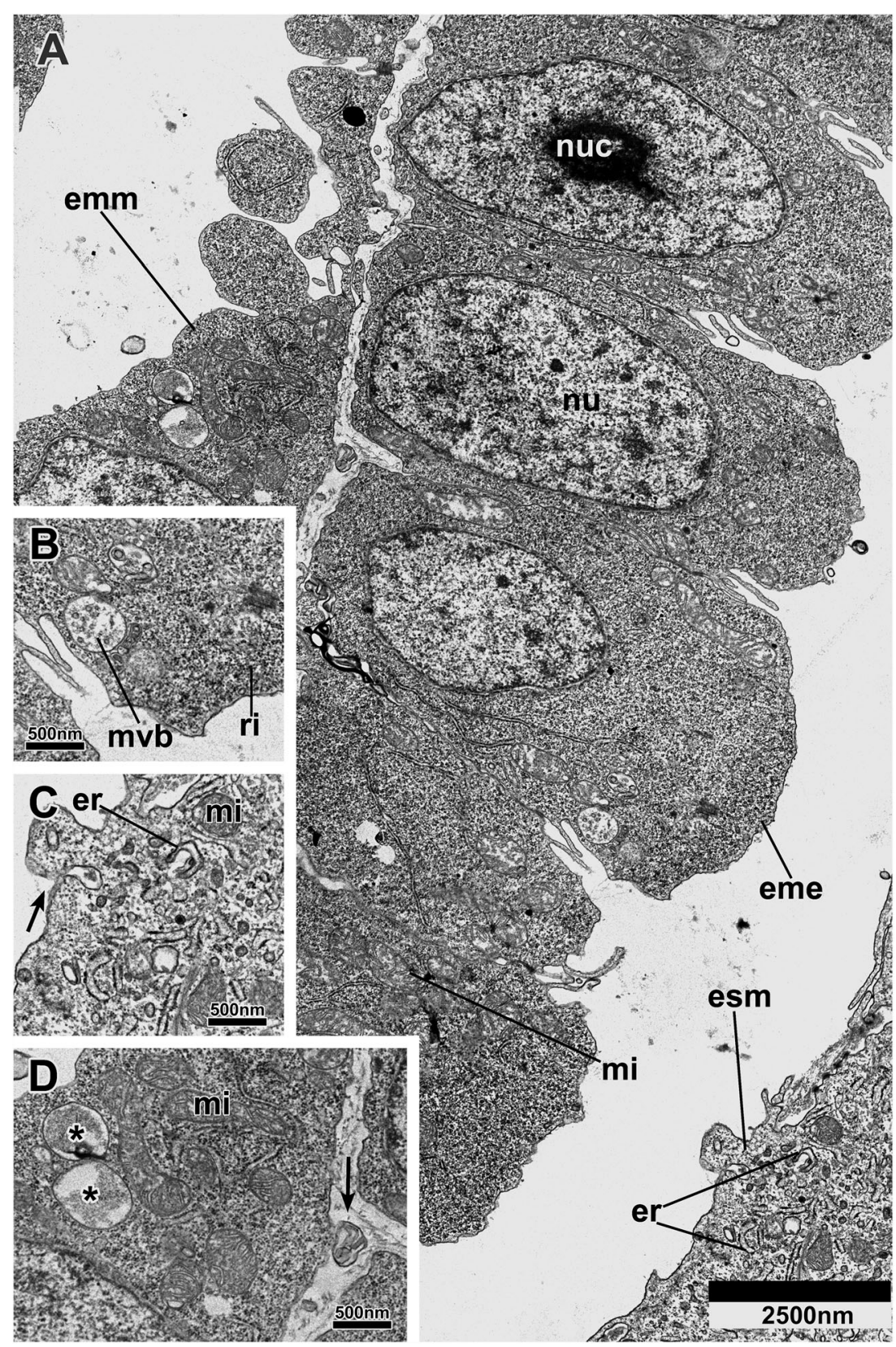

\section{Ultrastructural evidence of matrotrophy}

The term matrotrophy defines parental, extra-vitelline nutrition during offspring gestation. Different variants of matrotrophy evolved independently in more than 20 animal phyla including bryozoans (Ostrovsky et al. 2016). Its most elaborated form is placentotrophy with a placenta referred to as an intimate apposition or fusion of embryonic and maternal tissues providing substance exchange (Mossmann 1937). During incubation, a prominent increase in embryonic size and the formation of the temporary structures by the parent and/or embryo are indicative of matrotrophy (Ostrovsky et al. 2016). Embryonic enlargement during development accompanied by embryo sac growth were previously described in phylactolaemates (e.g. Davenport 1891), but not recognized as indication of matrotrophy. If contact cells or zones lack any specific nourishing function, embryos probably absorb nutrients via the entire ectodermal surface. In contrast, if intracellular transport does occur in the cells providing contacts between the embryo and the embryo sac, they could be considered as some sort of placental analogue.

Cytological details show that the mesodermal cells of the embryo sac have largely convoluted surfaces and include numerous vesicles that empty their flocculent content into the space between the embryo sac and the embryo in Plumatella casmiana. Similar mechanisms have been shown for the 


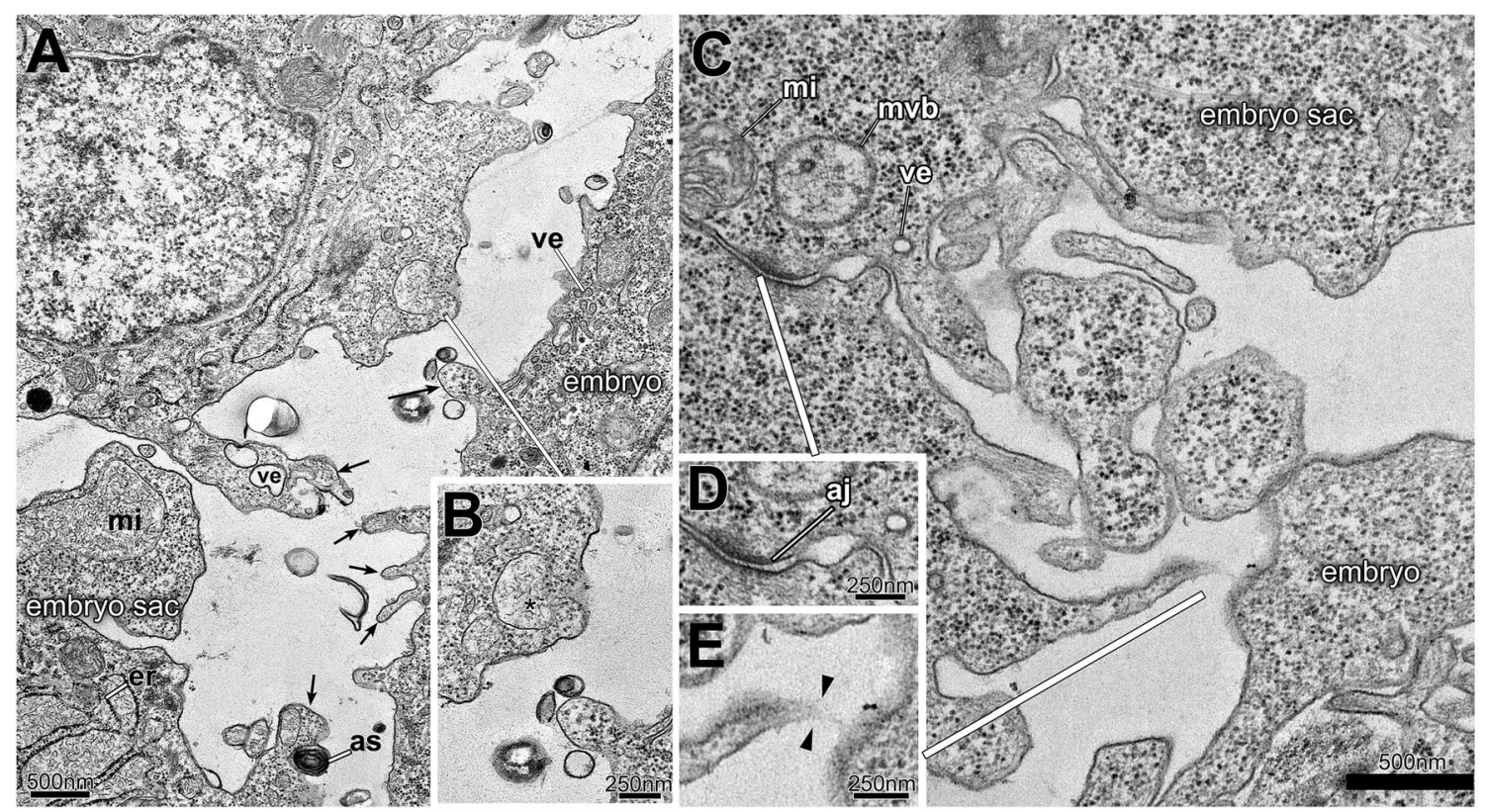

Fig. 19 Ultrastructural details of opposing embryonic and embryo sac tissues in Plumatella casmiana (TEM). a Embryo showing extensions towards the embryo sac and vice versa (arrows). b Massive cytoplasmic extensions of the embryo sac mesoderm including large vesicles, partly opening to the lumen of the embryo sac (asterisk). c Filiform extensions between the cells of the embryo sac and the embryo. d Cells of the embryo sac connected to each other via adherens junctions. e Possible contact area (arrowheads) between the cytoplasmic extensions of the embryo sac (left) and the embryo (right). Abbreviations: $a j$ adherens junction, as autophagosomes, $m i$ mitochondria, $m v b$ multi vesicular body, er endoplasmatic reticulum, ve vesicles

sac facing the body cavity also shows surface increasements in the form of infoldings in P. casmiana and is probably a sign of placental analogue of a matrotrophic cheilostome (Moosbrugger et al. 2012). The internal side of the embryo

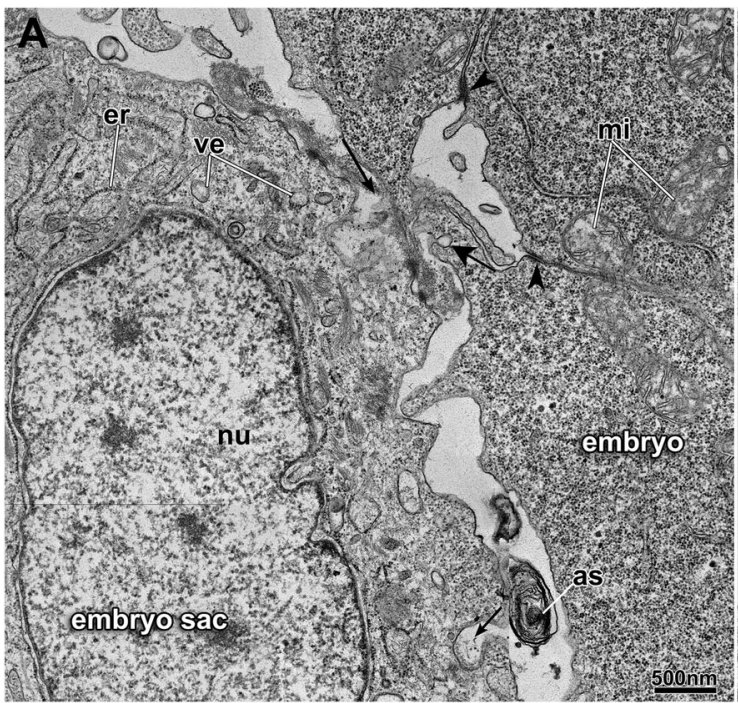

Fig. 20 Ultrastructure of the contact area between the embryo sac and the embryo (a, c, d) and the embryo sac facing the maternal coelom $(b, e)$ in Plumatella casmiana (TEM). a Mesodermal cell of the embryo sac (left) with a large nucleus and surrounding endoplasmatic reticulum. Vesicles release their contents (arrows) to the lumen of the embryo sac. A presumed endocytotic vesicle (wide arrow) is present in the cytoplasmic extension of the cell of the embryo. A large expelled(?) autophagosome is located in the lumen between the embryo sac and the embryonic cells, the latter with several cytoplasmic processes in contact with the former. Embryonic cells are interconnected by adherens junctions (arrowheads).

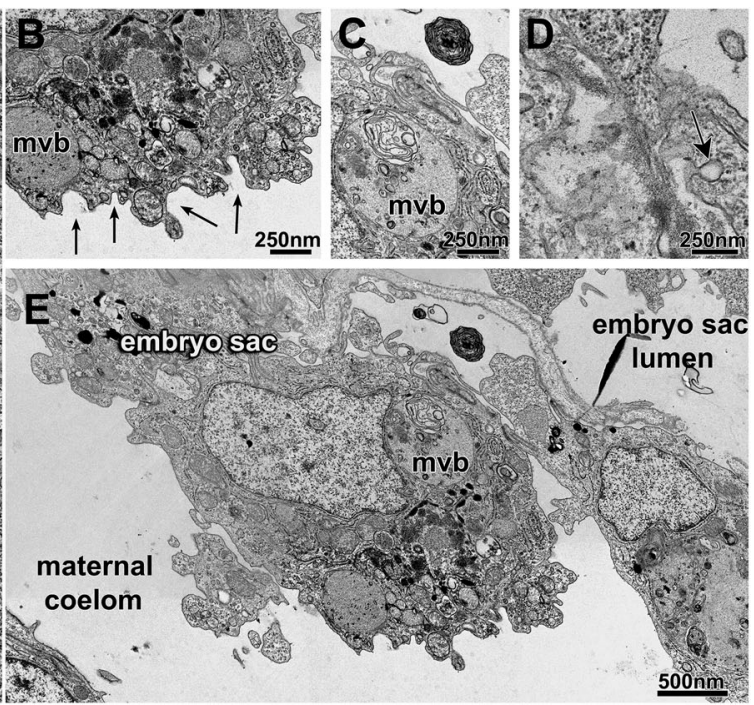

b Mesodermal cell of the embryo sac facing the maternal coelom and showing several pits (arrows) that presumably indicate endocytosis. c Large autophagosomes, one in the cell of the embryo sac and another located in the brood cavity. d Vesicle of a cell of the embryo sac (to the left) emptying its contents into the space between the embryo sac and the embryo. The embryonic cell shows a presumed endocytotic vesicle (wide arrow). e Embryo sac cell showing highly increased surfaces facing the maternal coelom and embryo sac lumen. Abbreviations: as autophagosomes, er rough endoplasmatic reticulum, $m i$ mitochondria, $m v b$ multi-vesicular body, $n u$ nucleus, ve vesicles 
endocytosis. In addition, the abundance of mitochondria, endoplasmatic reticulum and multivesicular bodies indicates that these cells are synthetically active and probably transport nutrients from the body cavity to the embryo sac lumen. A similar condition was recently shown in the placental analogue of cyclostome bryozoans (Nekliudova et al. 2021). Autophagosomes in the cells of the embryo sac are indications of membrane recycling as found in other matrotrophic bryozoans (Moosbrugger et al. 2012; Nekliudova et al. 2019). In matrotrophic bryozoans, the embryo receives nutrients from the brood sac lumen and shows an increase of its surface and signs of endocytosis in several bryozoans (Woollacott and Zimmer 1975; Hughes 1987; Moosbrugger et al. 2012; Schwaha et al. 2019; Nekliudova et al. 2019). Indications for endocytosis were rarely encountered in the current study from embryos of $P$. casmiana, but their outer surface is increased by abundant filiform cytoplasmic processes that face the embryo sac lumen and are probably involved in nutrient uptake.

In contrast to most matrotrophic gymnolaemates ( Woollacott and Zimmer 1975; Hughes 1987; Moosbrugger et al. 2012; Ostrovsky 2013a, b; Nekliudova et al. 2019), developing phylactolaemate embryos are completely surrounded by cells of the embryo sac once incubated. In most areas, the surface of the embryo is situated very close to the nutrient-providing cells of the embryo sac, which is characteristic of placental analogues of various animal clades (Ostrovsky et al. 2016). Uptake of nutrients in phylactolaemate embryos occurs via absorbotrophy (i.e. histotrophy) from the embryo sac cavity, with the embryonic external epithelium being in close contact with the embryo sac. This merits the terms placentation with the entire embryo sac wall acting as placental analogue. Histotrophy is thus an equivalent to placentotrophy in this case.

No implantation of the embryonic cells in the embryo sac was detected during our study (see also Ostrovsky 2013b). In Plumatella casmiana, cytoplasmic processes of embryonic cells in the contact zone are often surrounded by mesodermal cells of the embryo sac that are larger and thicker. These cells show different staining properties and have dark inclusions. So far there are no direct indications of intercellular transport between these cytoplasmic processes. Ultrastructural details of the ring-shaped contact zone are required to recognize its function since it is also possible that its cells have a nourishing function in later development.

\section{Evolution of sexual reproduction in Phylactolaemata}

Most phylactolaemates produce numerous small oligolecithal eggs (although just one becomes an embryo) which are reminiscent to the ancestral condition characteristic of zygotespawning of (mostly marine) gymnolaemates with planktotrophic larvae (Ostrovsky 2013a). The origin of embryonic incubation could be a prerequisite for the evolution of matrotrophy. The combination of numerous small oocytes and (presumably) matrotrophic incubation in an embryo sac associated with the cystid wall is known, for example, in the enigmatic bryozoan Labiostomella gisleni (Silén 1944; Ostrovsky 2013a, b). The transition to nourished embryos and non-feeding, short-lived larvae appears most likely. Among phylactolaemates, there are additional modifications from this reproductive mode with multiple oligolecithal oocytes and matrotrophic incubation: in Fredericella the amount of oocytes is reduced to very few. Plumatella evelinae possibly has mesolecithal oocytes instead of oligolecithal ones, and Lophopus crystallinus has putative nurse cells.

\section{Conclusions}

This study provides the first detailed analysis of the embryonic development of a phylactolaemate bryozoan, Plumatella casmiana, using 3D-reconstruction of several developmental stages. The mesoderm forms via delamination, not by unipolar immigration as previously described. Temporary contacts between the embryonic and maternal cells are abundant. These are largely formed by extensions of the embryonic ectodermal cells towards cells of the embryo sac, but few mesodermal cells of the brood sac also form such extensions. A ringshaped contact zone forms in late embryos, but its definitive function remains to be revealed. Ultrastructural details of the mesodermal cells of the embryo sac indicate transcellular transport presumably delivering nutrients from the coelom to the embryo sac cavity. Embryonic cells with filiform extensions are closely opposed to the wall of the embryo sac, which indicates placentation.

Acknowledgments Special thanks to Tim Wood (Wright State University) and Ratcha Chaichana (Kasetsart University) for aid in sampling in Thailand in 2009. Electron microscopy was performed at the Core Facility Cell Imaging and Ultrastructure Research, University of Vienna - member of the Vienna Life-Science Instruments (VLSI).

Authors' contributions TS and ANO designed the research. TS collected the material. TS and AW coordinated and supervised the study. JB conducted most of the practical analyses and drafted the manuscript. TS, ANO and AW contributed to the writing of the manuscript. All authors have read and approved the manuscript.

Funding Open access funding provided by University of Vienna. TS' trip to Thailand 2009 was supported by the KWA fund of the University of Vienna. Phylactolaemate research is currently supported by Austrian Science Fund (FWF) project P 32088 granted to TS. ANO thanks the Russian Science Fund (grant 18-14-00086) for financial support.

\section{Declarations}

Ethics approval and consent to participate Not applicable 


\section{Consent for publication Not applicable}

Availability of data and materials The datasets used and/or analysed in this study are available from the corresponding author upon request.

Competing interests The authors declare that they have no competing interests.

Open Access This article is licensed under a Creative Commons Attribution 4.0 International License, which permits use, sharing, adaptation, distribution and reproduction in any medium or format, as long as you give appropriate credit to the original author(s) and the source, provide a link to the Creative Commons licence, and indicate if changes were made. The images or other third party material in this article are included in the article's Creative Commons licence, unless indicated otherwise in a credit line to the material. If material is not included in the article's Creative Commons licence and your intended use is not permitted by statutory regulation or exceeds the permitted use, you will need to obtain permission directly from the copyright holder. To view a copy of this licence, visit http://creativecommons.org/licenses/by/4.0/.

\section{References}

Allman, G. J. (1856). A monograph of the Fresh-water Polyzoa. Ray Society.

van Beneden, P. J. (1839). Quelques observations sur les Polype d'eau douce. Bulletins de l'Académie Royale des Sciences, des Lettres et des Beaux-Arts de Belgique, 6, 276-279.

Braem, F. (1890). Untersuchungen über die Bryozoen des süßen Wassers. Zoologica, 6, 1-134.

Braem, F. (1897). Die geschlechtliche Entwicklung von Plumatella fungosa. Zoologica, 23, 1-96.

Braem, F. (1908a). Die Spermatozoen der Süßwasserbryozoen. Zoologischer Anzeiger, 32, 671-673.

Braem, F. (1908b). Die geschlechtliche Entwicklung von Fredericella sultana nebst Beobachtungen über die weitere Lebensgeschichte der Kolonien. Zoologica, 20, 1-38.

Braem, F. (1951). Über Victorella und einige ihrer nächsten Verwandten, sowie über die Bryozoenfauna des Ryck bei Greifswald. Zoologica, $102,1-59$.

Brien, P. (1936). Contribution à l'étude de la reproduction asexuée des phylactolémates. Mémoires du Musée royal d'histoire naturelle de Belgique,2e serie, 3, 569-625.

Brien, P. (1953). Etude sur les Phylactolemates. Annales de la Société royale zoologique de Belgique, 84, 301-444.

Brien, P., \& Mordant, C. (1955). Relations entre les reproductions sexuée et asexuée à propos des Phylactolémates. Ann. Soc. R. Zool. Belg., 86, 169-189.

Davenport, C. B. (1891). Observations on budding in Paludicella and some other Bryozoa. Bulletin of the Museum of Comparative Zoology at Harvard College, 22, 1-114.

D'Hondt, J. L. (2005). État des connaissances sur le développement embryonnaire des Bryozoaires Phylactolaemates. Denisia, 16, 5968.

Dumortier, B.-C., \& van Beneden, P. J. (1850). Histoire naturelle des Polypes composes d'eau douce ou des Bryozoaires fluviatiles. Bruxelles

Franzén, A. (1981). Comparative ultrastructural studies of spermatids and spermatozoa in Bryozoa and Entoprocta. In G. P. Larwood, \& C. nielsen (Eds.), Recent and Fossil Bryozoa. (pp. 83-92). : Olsen \& Olsen.
Franzen, A. (1982). Ultrastructure of spermatids and spermatozoa in the fresh water bryozoan Plumatella (Bryozoa, phylactolaemata). Journal of Submicroscopic Cytology, 14, 323-336.

Franzén, A., \& Sensenbaugh, T. (1983). Fine structure of the apical plate in the larva of the freshwater bryozoan Plumatella fungosa (Pallas) (Bryozoa: Phylactolaemata). Zoomorphology, 102, 87-98.

Freeland, J. R., Lodge, R. J., \& Okamura, B. (2003). Sex and outcrossing in a sessile freshwater invertebrate. Freshwater Biology, 48, 301305.

Gruhl, A. (2010). Neuromuscular system of the larva of Fredericella sultana (Bryozoa: Phylactolaemata). Zoologischer Anzeiger - A Journal of Comparative Zoology, 249, 139-149. https://doi.org/10. 1016/j.jcz.2010.06.001.

Handschuh, S., Baeumler, N., Schwaha, T., \& Ruthensteiner, B. (2013). A correlative approach for combining microCT, light and transmission electron microscopy in a single 3D scenario (Article). Frontiers in Zoology, 10, 44. https://doi.org/10.1186/1742-9994-10-44.

Hughes, D. J. (1987). Gametogenesis and embryonic brooding in the cheilostome bryozoan Celleporella hyalina. Journal of Zoology, 212, 691-711.

Hyman, L. H. (1959). The invertebrates. Vol. V. smaller coelomate groups. McGraw-Hill.

Jones, C. S., Okamura, B., \& Noble, L. R. (1994). Parent and larval RAPD fingerprints reveal outcrossing in freshwater bryozoans. Molecular Ecology, 3, 193-199.

Jullien, J. (1890). Observations sur la Cristatella mucedo. Memoires de la Societé Zoologique de France, 3, 361-395.

Korotneff, A. (1887a). Beiträge zur Spermatologie. Archiv für Mikroskopische Anatomie, 31, 334-341.

Korotneff, A. (1887b). Zur Entwicklung der Alcyonella fungosa. Zoologischer Anzeiger, 10, 193-194.

Korotneff, A. (1890). On the development of the Fresh-water Bryozoa. Zapiski Kievskago obshchestva estestvoispytateleĭ, 10, 393-412.

Kraepelin, K. (1886). Über die Phylogenie und Ontogenie der Süsswasserbryozoen. Biologisches Zentralblatt, 6, 599-602.

Kraepelin, K. (1892). Die deutschen Süßwasser-bryozoen. 2. Entwicklungsgeschichtlicher Teil. Abhandlungen aus dem Gebiete der Naturwissenschaften, hrsg. vom Naturwissenschafticher Verein in Hamburg, 12, 1-68.

Lützen, J., Jespersen, A., \& Nielsen, C. (2009). Ultrastructure of spermiogenesis in Cristatella mисеdo Cuvier (Bryozoa: Phylactolaemata: Cristatellidae). Zoomorphology, 128, 275-283. https://doi.org/10. 1007/s00435-009-0088-6.

Marcus, E. (1934). Über Lophopus crystallinus (PALL.). Zoologische Jahrbücher. Abteilung für Anatomie und Ontogenie der Tiere, 58 , 501-606.

Marcus, E. (1941). Sobre Bryozoa do Brasil. I. Boletim da Faculdade de filosofia, ciéncias e letras, Universidade di Sao Paolo, Zoologia, 5 , 3-208.

McKinney, F. K., \& Jackson, J. B. C. (1989). Bryozoan Evolution. Unwin Hyman.

Metschnikoff, E. (1871). Beiträge zur Entwicklung einiger niederer Tiere. 6. Alcyonella. Bull. de l'Acad. de St. Petersbourg., 15, 507-508.

Moosbrugger, M., Schwaha, T., Walzl, M. G., Obst, M., \& Ostrovsky, A. N. (2012). The placental analogue and the pattern of sexual reproduction in the cheilostome bryozoan Bicellariella ciliata (Gymnolaemata). Frontiers in Zoology, 9, 29. https://doi.org/10. 1186/1742-9994-9-29.

Mossmann, H. (1937). Comparative morphogenesis of the fetal membranes and accessory uterine structures. Carnegie Institution Contribution to Embryology, 26, 129-246.

Mukai, H. (1982). Development of freshwater bryozoans (Phylactolaemata). In F. W. Harrison \& R. R. Cowden (Eds.), Developmental biology of freshwater invertebrates (pp. 535-576). Alan R. Liss. Inc.. 
Mukai, H., Terakado, K., \& Reed, C. G. (1997). Bryozoa. In F. W. Harrison \& R. M. Woollacott (Eds.), Microscopic anatomy of invertebrates (pp. 45-206). Wiley-Liss.

Nekliudova, U. A., Schwaha, T. F., Kotenko, O. N., Gruber, D., Cyran, N., \& Ostrovsky, A. N. (2019). Sexual reproduction of the placental brooder Celleporella hyalina (Bryozoa, Cheilostomata) in the White Sea. Journal of Morphology, 280, 278-299. https://doi.org/10.1002/ jmor.20943.

Nekliudova, U. A., Schwaha, T., Kotenko, O. N., Gruber, D., Cyran, N., \& Ostrovsky, A. N. (2021). Three in one: evolution of viviparity, coenocytic placenta and polyembryony in cyclostome bryozoans. BMC Ecology Evolution, 21, 54.

Nitsche, H. (1872). Betrachtungen über die Entwicklungsgeschichte und Morphologie der Bryozoen. Zeitschrift für Wissenschaftliche Zoologie, 22, 467-472.

Oda, S. (1958). On the outflow of the blood in colonies of freshwater Bryozoa [japanese]. Kagaku (tokyo), 28, 37.

Oda, S. (1974). Pectinatella magnifica occuring in Lake Shoji, Japan. Proceedings of the Japanese Society of Systematic Zoology, 10, 31-39.

Oda, S., \& Nakamura, R. M. (1980). Sexual reproduction in Pectinatella gelatinosa, a freshwater bryozoan. Proceedings of the Japanese Society of systematic Zoology, 19, 38-44.

Oka, A. (1891). Observations on fresh-water Polyzoa. The Journal of the College of Science, Imperial University of Tokyo, Japan $=$ Tokyo Teikoku Daigaku kiyo. Rika., 4, 89-150.

Oka, H., \& Oda, S. (1948). Observations on freshwater Bryozoa with special reference to their reproduction [japanese]. Collect. Breed (Tokyo), 10, 39-48.

Okamura, B., \& Hatton-Ellis, T. (1995). Population biology of bryozoans - correlates of sessile, colonial life histories in fresh water habitats. Experientia, 51, 510-525.

Ostrovsky, A. N. (2008). External versus internal and self- versus crossfertilization in Bryozoa: transformation of the view and evolutionary considerations. In P. N. Wyse Jackson \& M. E. SpencerJones (Eds.), Annals of Bryozoology 2: aspects of the history of research on bryozoans (pp. 103-115). International Bryozoology Association, Dublin.

Ostrovsky, A. N. (2013a). Evolution of sexual reproduction in marine Invertebrates: Example of gymnolaemate bryozoans. Springer.

Ostrovsky, A. N. (2013b). From incipient to substantial: Evolution of placentotrophy in a phylum of quatic colonial invertebrates. Evolution, 67, 1368-1382. https://doi.org/10.1111/evo.12039.

Ostrovsky, A. N. (2020). Sexual reproduction in Bryozoa. In T. Schwaha (Ed.), Handbook of Zoology. Bryozoa (pp. 101-122). de Gruyter.

Ostrovsky, A. N., \& Porter, J. S. (2011). Pattern of occurrence of supraneural coelomopores and intertentacular organs in Gymnolaemata (Bryozoa) and its evolutionary implications. Zoomorphology, 130, 1-15. https://doi.org/10.1007/s00435-0110122-3.

Ostrovsky, A. N., \& Schäfer, P. (2003). Ovicell structure in Callopora dumerilii and C. lineata (Bryozoa: Cheilostomatida). Acta Zoologica, 84, 15-24.

Ostrovsky, A. N., Grischenko, A. V., Taylor, P. D., Bock, P. E., \& Mawatari, S. F. (2006). Comparative anatomical study of internal brooding in three anascan bryozoans (Cheilostomata) and its taxonomic and evolutionary implications. Journal of Morphology, 267, 739-749.

Ostrovsky, A. N., Dick, M. H., \& Mawatari, S. F. (2007). The internalbrooding apparatus in the bryozoan genus Cauloramphus (Cheilostomata : calloporidae) and its inferred homology to ovicells. Zoological Science, 24, 1187-1196. https://doi.org/10.2108/zsj.24. 1187.

Ostrovsky, A. N., Nielsen, C., Vavra, N., \& Yagunova, E. (2009a). Diversity of the brooding structures in calloporod bryozoans
(Gymnolaemata: Cheilostomata): comparative anatomy and evolutionary trends. Zooomorphology, 128, 13-35.

Ostrovsky, A. N., O'Dea, A., \& Rodriguez, F. (2009b). Comparative anatomy of internal incubational sacs in cupuladriid bryozoans and the evolution of brooding in free-living Cheilostomes. Journal of Morphology, 270, 1413-1430. https://doi.org/10.1002/jmor.10767.

Ostrovsky, A. N., Gordon, D. P., \& Lidgard, S. (2009c). Independent evolution of matrotrophy in the major classes of Bryozoa: transitions among reproductive patterns and their ecological background. Marine Ecology-Progress Series, 378, 113-124. https://doi.org/10. 3354/meps07850.

Ostrovsky, A. N., Lidgard, S., Gordon, D. P., Schwaha, T., Genikhovich, G., \& Ereskovsky, A. V. (2016). Matrotrophy and placentation in invertebrates: a new paradigm. Biological Reviews, 91, 673-711. https://doi.org/10.1111/brv.12189.

Reed, C. G. (1991). Bryozoa. In A. C. Giese, J. S. Pearse, \& V. B. Pearse (Eds.), Reproduction of marine Invertebrates. VI. Echinoderms and Lophophorates (pp. 85-245). The Boxwood Press.

Reinhard, W. W. (1881). Skizze des Baues und der Entwicklung der Süßwasser Bryozoen. Arbeiten der Naturforschenden-Gesellschaft in Charkow, 15, 207-310.

Retzius, G. (1909). Weiteres zur Kenntnis der Spermien der Bryozoen. Biologische Untersuchungen, 14, 75-76.

Rogick, M. D. (1939). Studies on Fresh-Water Bryozoa VIII. Larvae of Hyalinella punctata (Hancock), 1850. Transactions of the American Microscopical Society, 58, 199-209.

Ruthensteiner, B. (2008). Soft Part 3D visualization by serial sectioning and computer reconstruction. Zoosymposia, 1, 63-100.

Ryland, J. S. (1970). Bryozoans. Hutchinson University Library.

Ryland, J. S. (2005). Bryozoa: an introductory overview. Denisia, 19, 9 20.

Santagata, S. (2015). Ectoprocta. In A. Wanninger (Ed.), Evolutionary Developmental Biology of Invertebrates. Vol.2: Lophotrochozoa (pp. 247-262). Springer.

Schölzel, G. (1951). Statoblasten und Larven von Cristatella im Lichte der Vitalfärbung. Zoologischer Anzeiger, 146, 177-187.

Schwaha, T. (2020a). Morphology of bryozoans. In T. Schwaha (Ed.), Handbook of Zoology: Bryozoa (pp. 57-100). DeGruyter.

Schwaha, T. (2020b). Phylactolaemata. In T. Schwaha (Ed.), Handbook of Zoology, Bryozoa (pp. 189-224). De Gruyter.

Schwaha, T., Handschuh, S., Redl, E., \& Wanninger, A. (2015). Insights into the organization of plumatellid 'larvae' (Lophotrochozoa, Bryozoa) by means of $3 \mathrm{D}$ imaging and confocal microscopy. Journal of Morphology, 276, 109-120.

Schwaha, T., Moosbrugger, M., Walzl, M., \& Ostrovsky, A. N. (2019). First ultrastructural evidence of placental nutrition in a ctenostome bryozoan: example of Amathia verticillata. Zoomorphology, 138, 221-232. https://doi.org/10.1007/s00435-019-00438-4.

Schwaha, T., Ostrovsky, A. N., \& Wanninger, A. (2020). Key novelties in the evolution of aquatic colonial phylum Bryozoa: Evidence from soft body morphology. Biological Reviews, 95, 696-729.

Sensenbaugh, T., \& Franzén, Å. (1998). Ultrastructural study of metamorphosis in the freshwater bryozoan Plumatella fungosa (Bryozoa Phylactolaemata). Invertebrate Reproduction and Development, 34 , 301-308.

Silén, L. (1944). The anatomy of Labiostomella gisleni Silen (Bryozoa Protocheilostomata). Kungliga Svenska Vetenskapsakademiens Handlingar Ser., 3(21), 1-111.

Silén, L. (1945). The main features of the development of the ovum, embryo and ooecium in the ooeciferous Bryozoa Gymnolaemata. Arkiv för Zoologi, 35A, 1-34.

Ström, R. (1977). Brooding patterns of bryozoans. In R. M. Woollacott \& R. L. Zimmer (Eds.), Biology of bryozoans (pp. 23-55). Academic Press. 
Taylor, P. D., \& Waeschenbach, A. (2015). Phylogeny and diversification of bryozoans. Palaeontology, 58, 585-599. https://doi.org/10. 1111/pala.12170.

Tazima, I., Inoue, S., \& Gopal Dutt, N. H. (1984). Oogenesis in the freshwater bryozoan, Pectinatella gelatinosa: Light microscopy. Zeitschrift für mikroskopisch-anatomische Forschung, 98, 193-197.

Tazima, I., Inoue, S., \& Gopal Dutt, N. H. (1993). Spermatogenesis in the freshwater bryozoan Pectinatella gelatinosa: light microscopy. Proceedings of the National Academy of Sciences India Section B (Biological Sciences), 63, 301-304.

Waeschenbach, A., Taylor, P. D., \& Littlewood, D. T. J. (2012). A molecular phylogeny of bryozoans. Molecular Phylogenetics and Evolution, 62, 718-735. https://doi.org/10.1016/j.ympev.2011.11. 011.
Wiebach, F. (1953). Über den Ausstoss von Flottoblasten bei Plumatellen. Zoologischer Anzeiger, 151, 266-272.

Wood, T. S. (2014). Phyla Ectoprocta and Entoprocta (Bryozoans). In J. H. Thorp \& D. C. Rogers (Eds.), Ecology and General Biology, Vol I: Thorp and Covich's Freshwater Invertebrates (4th ed., pp. 327345). Academic Press. https://doi.org/10.1016/b978-0-12-3850263.00016-4.

Woollacott, R. M., \& Zimmer, R. L. (1975). A simplified placenta like system for the transport of extraembryonic nutrients during embryogenesis of Bugula neritina (Bryozoa). Journal of Morphology, 147, $355-378$.

Publisher's note Springer Nature remains neutral with regard to jurisdictional claims in published maps and institutional affiliations. 